I N T ER N ATIONAL MONETARY FUND

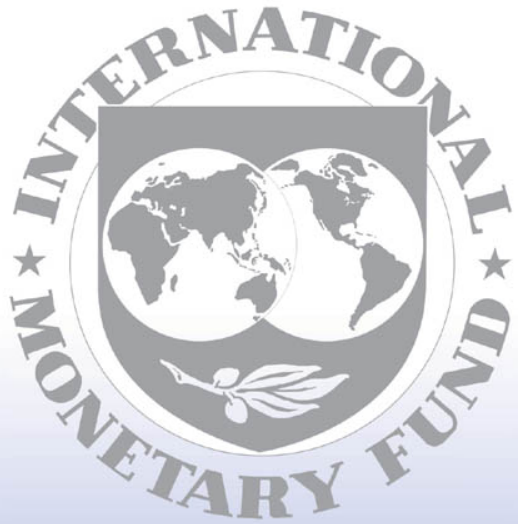

Staff

Country

Reports 


\section{Sweden: 2004 Article IV Consultation-Staff Report; Staff Statement; Public Information Notice on the Executive Board Discussion; and Statement by the Executive Director for Sweden}

Under Article IV of the IMF's Articles of Agreement, the IMF holds bilateral discussions with members, usually every year. In the context of the 2004 Article IV consultation with Sweden, the following documents have been released and are included in this package:

- $\quad$ the staff report for the 2004 Article IV consultation, prepared by a staff team of the IMF, following discussions that ended on May 19, 2004, with the officials of Sweden on economic developments and policies. Based on information available at the time of these discussions, the staff report was completed on July 2, 2004. The views expressed in the staff report are those of the staff team and do not necessarily reflect the views of the Executive Board of the IMF.

- $\quad$ a staff statement of August 4, 2004 updating information on recent developments.

- a Public Information Notice (PIN) summarizing the views of the Executive Board as expressed during its August 4, 2004 discussion of the staff report that concluded the Article IV consultation.

- $\quad$ a statement by the Executive Director for Sweden.

The document listed below have been or will be separately released.

Selected Issues Paper

The policy of publication of staff reports and other documents allows for the deletion of market-sensitive information.

To assist the IMF in evaluating the publication policy, reader comments are invited and may be sent by e-mail to publicationpolicy@imf.org.

Copies of this report are available to the public from

International Monetary Fund • Publication Services
$70019^{\text {th }}$ Street, N.W. • Washington, D.C. 20431
Telephone: (202) 623-7430 • Telefax: (202) 623-7201
E-mail: publications@imf.org • Internet: http://www.imf.org

Price: $\$ 15.00$ a copy

International Monetary Fund

Washington, D.C. 


\section{INTERNATIONAL MONETARY FUND}

\section{SWEDEN \\ Staff Report for the 2004 Article IV Consultation}

Prepared by Staff Representatives for the 2004 Consultation with Sweden

Approved by Ajai Chopra and Martin Fetherston

July 2, 2004

- $\quad$ A staff team comprising Messrs. Thakur (Head), Bonato, Ms. Lusinyan (all EUR), and Mr. Danninger (FAD) visited Stockholm during May 10-19, 2004. The mission met senior officials of the Riksbank and the Ministry of Finance, as well as representatives of the Association of Local Authorities, the Confederation of Trade Unions, the Confederation of Swedish Enterprises, the private financial sector and the academic community. Mr. Farelius, Advisor, Nordic-Baltic Executive Director's Office, participated in the discussions.

- $\quad$ The authorities published the Concluding Statement of the mission and have expressed their intention to publish this staff report.

- A minority Social Democratic Party government was re-elected in September 2002 and governs with the support of the Left and Green Parties. Next elections are due in Fall 2006. Swedish voters rejected entry into the European Monetary Union in a referendum held in September 2003.

- $\quad$ Sweden has accepted the obligations of Article VIII of the Articles of Agreement; and subscribes to the Special Data Dissemination Standard. Data provision is timely and facilitates effective surveillance (Appendix I).

The last Article IV consultation was concluded on July 25, 2003, with Executive Directors commending Sweden's strong economic record and the authorities' welldesigned macroeconomic framework. Directors, however, expressed concern that the continued rise in discretionary public spending had begun to undermine the strong fiscal position and the prospects for a lasting reduction in Sweden's high tax burden. Noting the rising problem of sickness absence, Directors called for renewed efforts to streamline the generous social insurance system in order to ensure fiscal sustainability and reduce disincentives to work. Directors also underscored the need for an impetus to measures aimed at reducing barriers to competition and improving the functioning of product and labor markets. 
Executive Summary $\underline{4}$

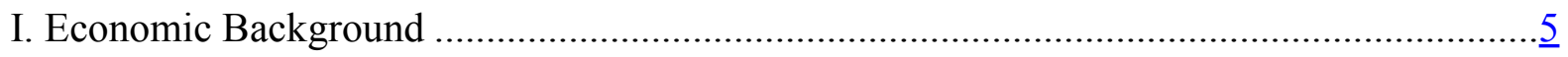

II. The Policy Setting and The Short-Term Outlook ................................................

III. The Policy Discussions ....................................................................................

A. Monetary Policy and the Financial Sector ...................................................

B. Fiscal Policy and the Fiscal Framework .................................................. 10

C. Structural Policies and Other Issues.......................................................... 14

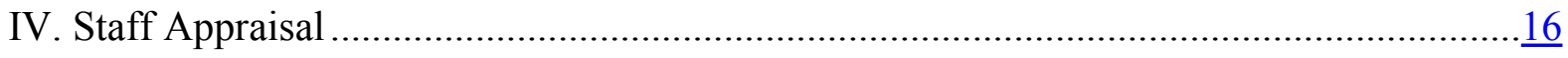

Figures

1. Output Developments and Prospects ................................................................20

2. Labor Market Developments ........................................................................

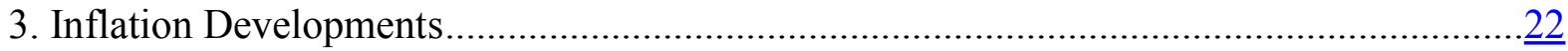

4. Exchange Rate Developments ..........................................................................

5. Asset Price and Interest Rate Developments ................................................... 24

6. Fiscal Developments and Prospects ............................................................

7. Sick Leave and Main Changes in Sickness Compensation System................................26

Tables

1. Selected Economic Indicators.........................................................................27

2. General Government Financial Accounts, 1998-2006 .................................................28

3. Balance of Payments, 1998-2009 ........................................................................29

4. Indicators of External and Financial Vulnerability, 1998-2004 ....................................30

5. Public Sector Debt Sustainability Framework, 1999-2009 .........................................

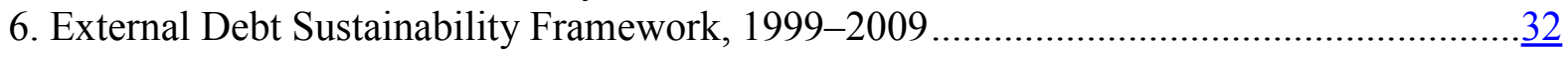

Boxes

1. Local Government and the Tax Burden ...........................................................

2. The Problem of Sickness Absence..................................................................

Appendices

I. Fund Relations .......................................................................................

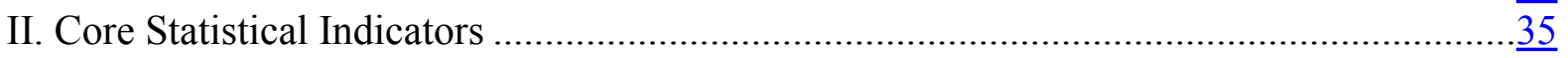




\section{Main Websites for Swedish Data}

Data in this Staff Report reflects information received by June 15, 2004. In many cases, more recent data can be obtained directly from the following internet sources:

Statistics Sweden http://www.scb.se/eng/index.asp

The Riksbank http://www.riksbank.com/

Ministry of Finance http://www.sweden.gov.se/sb/d/2062

National Institute of Economic Research. http://www.konj.se/4.2f48d2f18732142c7fff4422.html

Additional information and documentation on Swedish economic statistics can be found at the Fund's SDDS website http://dsbb.imf.org/Applications/web/sddscountrycategorylist/?strcode=SWE and at Statistics Sweden's Economic Data Portal: http://www.scb.se/ekonomi/ekonomieng.asp\#area 


\section{EXECUTIVE SUMMARY}

Background and Outlook: Supported by a strong fiscal stimulus, the economy underwent only a mild downturn in 2002-03, with growth remaining well above the EU average. Economic activity is expected to pick up steadily as the global recovery gains strength. Inflation pressures remain low thanks to strong productivity gains, economic slack, and falling import prices. Persistent weakness in the labor market contributed to wage moderation. With inflation forecast to remain below the 2 percent target, the Riksbank eased policy aggressively in early 2004, cutting its policy rate to a historic low of 2 percent. Although still comfortable in the EU context, the fiscal position has weakened as new spending initiatives jeopardize the expenditure ceilings and further delay the return to the structural surplus target of 2 percent. Financial markets took in stride the rejection of the euro in the September 2003 referendum.

Policy discussions centered on the following key issues:

- $\quad$ The stance of short-term policies in light of the outlook for growth, employment and inflation in 2004-05: While the Riksbank's policy of keeping rates on hold was appropriate for now, monetary policy would need to be tightened if upside risks began to materialize.

- The prospects for attaining the authorities' medium-term fiscal surplus target and the growing risks to the framework of fiscal rules: The authorities and the mission agreed that with the fiscal framework under strain, it was important to maintain a firm commitment to the expenditure ceilings. The staff recommended that a more ambitious fiscal adjustment in 2005-06 was needed to meet the structural surplus target. The mission underscored its view that safeguarding the surplus target was central to maintaining confidence in the fiscal framework.

- $\quad$ The necessity of addressing the rising tensions in the public finances: These tensions are evident in the pressures on expenditures, the finances of local authorities, and the distortions stemming from the tax-transfer system: In the mission's view, a reform of the tax-benefit system to encourage effective labor supply was highly desirable. Raising effective labor supply would help raise potential growth and reduce tensions in public finances in the face of the coming demographic transition. Greater policy coordination between central and local levels of government would help smooth fluctuations in local revenue and alleviate local tax increases.

- The need to strengthen the structural agenda: In the mission's view, faster progress was desirable, particularly in the areas of tax, labor, and product market reform, in the light of challenges from demography, EU enlargement, and rapid globalization. Encouraging effective labor supply is the most important long-term challenge. The authorities agreed that there was scope for progress in reducing sickness absence, promoting greater competition in product markets, and improving the functioning of labor markets.

- The risks to the financial system: Despite some concern about rising household debt, the financial system remained sound. 


\section{ECONOMIC BACKGROUND}

\section{Sweden's strong economic performance in recent years is grounded in a} credible, rule-based policy framework. The framework, centered on a medium-term fiscal strategy and a well-designed inflation targeting regime, has underpinned the authorities' success in combining monetary and financial stability with solid economic growth. With Swedish voters' rejection of entry into the EMU, the inflation targeting framework will continue to anchor monetary stability for the foreseeable future. The fiscal framework, while well-designed, has however begun to experience growing strains under rising spending pressures.

\section{The Swedish downturn was unusually mild, with growth remaining well above}

the EU average in 2002-03 (Figure 1). Expansionary fiscal policy-the fiscal stimulus in 2002 was around 3 percent of GDP in contrast to the neutral stance in the euro areacombined with low interest rates underpinned private consumption. However, the momentum of activity slowed in the first half of 2003, as the impact of public sector demand waned and private investment failed to revive. As external demand picked up in the second half, the pace of activity accelerated, with the telecom sector, a driver of the earlier period of rapid growth, recovering after a prolonged slump. ${ }^{1}$ A notable element in sustaining growth has been a strong rise in productivity. While partly cyclical, productivity growth also suggests

\begin{tabular}{lrrrrr}
\multicolumn{7}{c}{$\begin{array}{c}\text { GDP and Demand } \\
\text { (percentage changes) }\end{array}$} \\
\cline { 2 - 7 } & 2001 & 2002 & 2003 & 2004 & 2005 \\
\cline { 2 - 7 } & 0.9 & 2.1 & 1.6 & 2.5 & 2.6 \\
\hline Real GDP & -0.2 & 0.9 & 1.0 & 1.6 & 3.0 \\
Domestic demand & 0.6 & 2.0 & 1.5 & 1.8 & 2.0 \\
Consumption & 0.4 & 1.4 & 1.9 & 2.2 & 2.8 \\
$\quad$ Private & 0.9 & 3.2 & 0.6 & 1.1 & 0.7 \\
Government & -1.0 & -3.0 & -2.0 & 1.5 & 8.1 \\
Gross fixed capital formation & 0.2 & 1.2 & 5.5 & 8.5 & 6.1 \\
Exports & -2.5 & -1.9 & 5.0 & 7.5 & 7.7 \\
Imports & &
\end{tabular}

Sources: Statistics Sweden, Riksbank, Ministry of Finance, and staff estimates. significant efficiency gains from the diffusion of new technologies throughout the economy. The steady upturn, driven by exports and household demand, has continued in early 2004.

\footnotetext{
${ }^{1}$ The fortunes of Ericsson, Sweden's flagship technology company, have symbolized the ups and downs of the world telecom sector in recent years. A leading producer of mobile telecom infrastructure and Sweden's largest exporter, the company suffered a massive decline in sales and a loss of profitability in the technology crash of 2000-02. Having gone through a painful restructuring process that trimmed its workforce by more than half over the past three years, the company seems poised to benefit from a recovery in world markets.
} 


\section{The recent recovery has not yet turned around the decline in employment and} average hours worked. Reflecting continued labor shedding by the business sector and by local governments facing strained finances, unemployment rose sharply, reaching a high of 6 percent in February 2004 from 4.5 percent a year earlier (Figure 2). The average duration of unemployment increased as did youth unemployment. In recent years, the high rate of sickness absence from work has been primarily responsible for the fall in the average hours worked. Although sickness absence leveled off in 2003, the adverse impact of overall ill health on the growth of labor supply continued to rise as many on long-term sick leave shift to disability pension.

\begin{tabular}{lrrrrr}
\multicolumn{5}{c}{$\begin{array}{c}\text { Inflation, Labor Market and Output Gap } \\
\text { (annual change in percent) }\end{array}$} \\
& 2001 & 2002 & 2003 & 2004 & 2005 \\
\cline { 2 - 6 } & & & & proj. & proj. \\
\hline CPI & 2.6 & 2.4 & 2.1 & 0.4 & 1.2 \\
Underlying inflation & 2.8 & 2.6 & 2.3 & 0.9 & 1.1 \\
Underlying domestic inflation & 3.8 & 3.5 & 3.6 & 1.7 & 1.6 \\
Nominal wage 1/ & 4.1 & 3.9 & 3.3 & 3.3 & 3.5 \\
Labor productivity 1/ & 0.4 & 4.1 & 3.7 & 3.2 & 2.5 \\
Unit labor costs 1/ & 4.7 & -0.4 & 1.2 & -0.4 & 1.2 \\
Employment & 1.9 & 0.1 & -0.2 & -0.5 & 0.7 \\
Hours worked & 0.5 & -1.2 & -1.3 & 0.1 & 0.7 \\
Open unemployment rate 2/ & 4.0 & 4.0 & 4.9 & 5.5 & 5.2 \\
Labor market programs 2/ & 2.5 & 2.6 & 2.1 & 2.3 & 2.1 \\
Output gap 3/ & -0.1 & -0.1 & -0.9 & -1.2 & -1.0 \\
\hline Sources: Riksbank, Ministry of Finance & & & & \\
1/ Corporate sector & & & & & \\
2/ In percent of labor force & & & & & \\
3/ In percent of potential output & & & & &
\end{tabular}

\section{Strong labor productivity growth coupled with economic slack dampened} inflation pressures, widening the room for monetary easing. After a spike in early 2003, driven by rising energy prices, inflation fell back toward the 2 percent target (Figure 3 ). Although the further fall in the annual inflation rate in early 2004 was anticipated on account of base-year effects, strong productivity growth and falling import prices contributed to a more rapid fall in inflation than expected, bringing it below the 2-percent target. The restraining impact of wage moderation on labor costs also helped accelerate the disinflation process. Inflation expectations, as measured by household and business surveys, have remained low, with inflation expected to be below target one year ahead, gradually rising toward 2 percent over a 2-year horizon.

\section{The competitive position remained strong, reflected in the large surplus on the} external current account. Financial markets took in stride the rejection of the euro in the September 2003 referendum. The krona was broadly unchanged vis-à-vis the euro, but appreciated by over 6 percent in effective terms in the year to March 2004, reflecting the weaker U.S. dollar, and by 3 percent in real effective terms, measured by relative unit labor costs (Figure 4). Nevertheless, with the krona remaining undervalued (see $₫ 13$ below) and with no further worsening of the terms of trade, the current account surplus rose from 5.4 percent of GDP in 2002 to a record-high of 6.4 percent of GDP in 2003 (Table 3). Longterm interest rates generally moved in line with those abroad and the differential with Germany, after a brief spike following the euro referendum, fell to around 40 basis points in April 2004. Led by a rebound in Ericsson's share price, the Swedish stock market rose by 30 percent in 2003, outperforming many overseas exchanges (Figure 5). In the first five months of 2004, stock prices have risen by around 6 percent. 


\section{The Policy Setting And The Short-Term Outlook}

6. While the fiscal framework is well-designed, adherence to it has slipped in recent years, primarily due to rising discretionary spending. The framework is built around a structural surplus target of 2 percent of GDP at the general government level, complemented by expenditure ceilings for the central government and a balanced budget rule for the local authorities. The surplus target was last met in 2001 . While a year ago, the official expectation was that the target would be reached in 2005, new spending initiatives in the Spring 2004 Budget now preclude the possibility of meeting the target at least until 2007. Official estimates suggest that, on present policies, cumulative deviations from the surplus

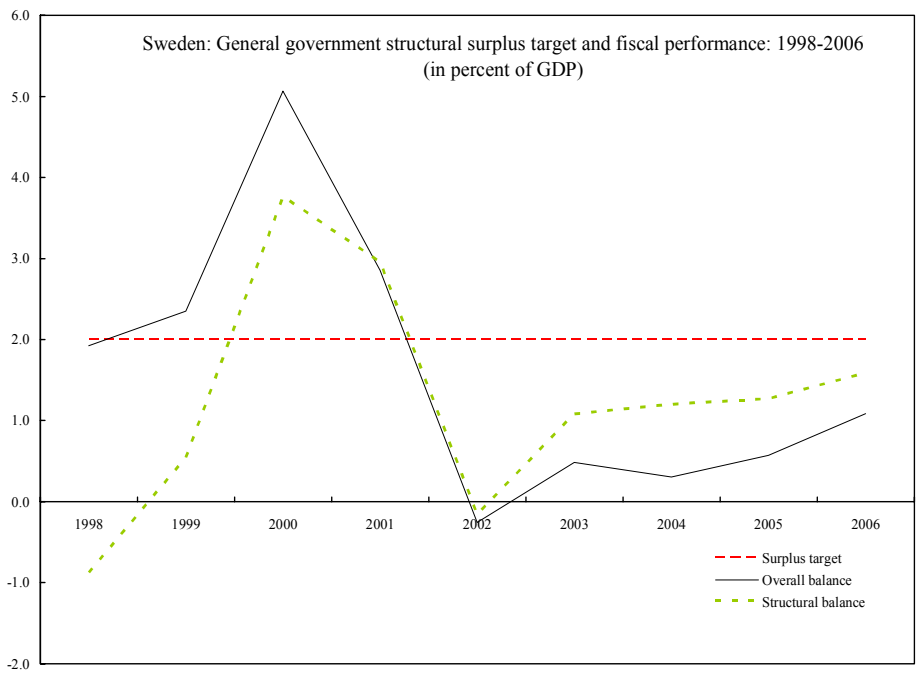
target would rise to 4 percent of GDP by 2006.

7. The budget for $\mathbf{2 0 0 4}$ is broadly neutral, reflecting the expectation of a recovery. The overall balance of the general government is planned to show a modest surplus. With new spending initiatives in areas such as labor market programs and social assistance, and increased grants to local authorities, only a marginal rise in the structural balance is envisaged. The margins under the expenditure ceilings are once again too narrow to provide any leeway in the event of unexpected shocks.

8. With inflation falling faster than expected and forecast to remain below target, the Riksbank eased policy aggressively in early 2004. While taking note of the uncertainty in assessing the cyclical and trend components of the recent strong productivity growth, the Riksbank has tended toward a cautiously optimistic view. Policy was eased gradually during 2003. Reacting to continued declines in actual and forecast inflation, the Riksbank cut its policy rate by 25 basis points in February 2004 and by another 50 basis points in early April to 2 percent, its lowest level for more than 50 years. The Swedish policy rate is now at the same level as in the euro area. Signaling the end of an easing cycle, the Riksbank then shifted to a neutral policy bias and left the rate unchanged in May.

9. As the global recovery gathers pace, economic activity in Sweden is expected to pick up steadily in 2004-05. Adjusted for calendar effects, output is expected to rise by around 2 percent, rather than the unadjusted forecast of $2 \frac{1}{2}$ percent, implying a lower utilization of resources. Indeed, the recovery over the coming year is unlikely to be accompanied by substantial gains in employment. The supportive monetary and fiscal policy 
stance and rising household confidence should stimulate private consumption, and improved demand prospects and profit position of manufacturing should assist a revival in business investment. Barring a sustained spike in oil prices, strong productivity gains and moderate wage increases would be expected to keep inflation below the target of 2 percent. The risks to this scenario are evenly balanced. The external demand stimulus could be larger than expected, especially if the krona continued to remain undervalued. However, protracted weakness in the labor market could hold back consumer spending and persistent excess capacity in manufacturing could again postpone the projected pick up in business investment.

\section{The Policy Discussions}

10. The discussions took place on the backdrop of Sweden's recent solid record of growth and stability, but rising fiscal strains and the emerging challenges presented by the demographic transition and EU enlargement. With Sweden's decision to remain outside the euro area, the inflation targeting framework will remain central to ensuring monetary stability. The Fund has viewed this framework and the Riksbank's operation of it as consistent with international best practice. While the fiscal framework has also generally been regarded as well-designed, the recent deviation from the fiscal target has raised concerns. The staff and the Executive Board have consistently urged a strict adherence to the framework to ensure fiscal sustainability and create room to reduce the high tax burden. The authorities' phased program of tax cuts is on hold for now, in view of the fiscal position. The Fund has also continued to argue the case for further streamlining the welfare state. ${ }^{2}$ The authorities, while not disagreeing in principle on the desirability of improving the incentive structure to encourage greater work effort and promoting competition, have preferred a more modest pace of reform. With the recent EU enlargement and the ongoing process of global economic integration, the issue of how to spark greater dynamism and growth in the Swedish economy has become more urgent.

\section{In this light, the discussions centered on the following key themes:}

- $\quad$ The stance of short-term policies in light of the outlook for growth, employment and inflation in 2004-05;

- $\quad$ The prospects for attaining the authorities' medium-term fiscal surplus target and the growing risks to the framework of fiscal rules;

\footnotetext{
2 The staff's case for reform of the Swedish model has been elaborated in a recent Fund publication and was the subject of a post-mission conference held in Stockholm, with participation by Swedish academics, parliamentarians, the mission chief Subhash Thakur and EUR Director Michael Deppler. See Subhash Thakur, Michael Keen, Balazs Horvath, and Valerie Cerra, 2003, Sweden's Welfare State-Can the Bumblebee Keep Flying?, (Washington, International Monetary Fund).
} 
- $\quad$ The necessity of addressing the rising tensions in the public finances, as reflected in the pressures on expenditures, the finances of local authorities, and the distortions stemming from the tax-transfer system; ${ }^{3}$

The need to strengthen the structural agenda, particularly in the areas of tax, labor, and product market reform, in the light of challenges from demography, $E U$ enlargement, and globalization.

\section{A. Monetary Policy and the Financial Sector}

12. The Riksbank forecasts inflation to remain below target over the next two years, but on a gradually upward path. The central scenario in the June 2004 Inflation Report, published soon after the conclusion of the discussions, projects the 12-month inflation at just over 1 percent by mid-2005, steadily rising to around 21/4 percent by mid-2006. The Riksbank viewed the risks on the domestic side as broadly balanced, with the expected strength of productivity growth helping to restrain costs as resource utilization rose. The upside risk to the forecast was dominated by the possibility that the global as well as the Swedish upturn could prove to be stronger than expected and that geopolitical factors could lead to sustained high oil prices. In the latter event, there was also a risk of second-round effects on wages. Although the results of the recently concluded 3 -year wage agreements have been moderate, local authority wage outcomes for 2005 could be higher than expected. In sum, upside risks would begin to predominate beyond the one-year horizon.

\section{Looking ahead, there was agreement that monetary policy would need to be} tightened if upside risks began to materialize as the recovery proceeded. The Riksbank's decision to keep the policy rate on hold for now was viewed as appropriate by the mission. It noted, however, that the eventual tightening would have to occur earlier rather than later if the stance of fiscal policy was not adequately tight. The Riksbank officials concurred with the mission's view that the krona remained undervalued, although their estimate of the extent of undervaluation was lower than that of the staff. ${ }^{4}$ In any event, markets expected the krona to appreciate further in view of the prospects for solid growth and productivity gains in the Swedish economy and sustained large current account surpluses. Any significant appreciation would tend to dampen inflation, although recent evidence for Europe and research by the Riksbank suggested that the pass-through could be protracted.

\footnotetext{
${ }^{3}$ Two Selected Issues papers prepared by the mission, on local government finances and sickness absence, served as background to the discussions.

${ }^{4}$ Most model-based econometric estimates suggest that the krona has been weaker than its equilibrium value. The staff's latest estimate, based on the macroeconomic balance approach as well as a panel estimation of purchasing power parity adjusted for fundamental factors such as terms of trade, relative productivity and income flows on net foreign assets, suggests an undervaluation of around 10 percent.
} 


\section{The Riksbank officials agreed that communication of their policy framework} could be improved by underscoring the role of the CPI as the only target variable. With expectations firmly anchored to the CPI as the target variable, the Riksbank has focused its forecast on the CPI over a one- to two-year horizon, but highlighted various measures of underlying inflation to rightly underscore that policy would not try to counter the effects of transitory shocks that cause projected inflation to deviate from its target level. Officials did not dispute that occasional confusion as to the precise target variable could be avoided by making explicit the role of judgment in inflation assessments and by extending the forecast horizon beyond two years. Indeed, Riksbank officials, in their recent public expositions of policy conduct, have considered the latter option. Looking ahead, the planned change in Statistics Sweden's method of calculation of the CPI from January 2005 is expected to lead to the recorded inflation rate being 0.2 percentage point per year lower as compared to the one based on the current method. This measurement change would have an one-off effect of appearing to raise the inflation target and this is being explained by the Riksbank in its communication to the public.

15. Indicators of financial system health remain favorable. Bank profitability has risen, partly reflecting cost reductions, and banks have strengthened their balance sheets further in the context of greater competition. Household debt, as in many other countries, has continued to rise, with the ratio of debt to disposable income up from 90 percent in the mid-1990s to about 120 percent. However, interest payments are only 5 percent of disposable income, compared with 11 percent in the early 1990s, and household assets exceed their liabilities. Simulations by the Riksbank suggest that even a relatively steep rise in interest rates would not significantly impair households' ability to service debt. ${ }^{5}$ The rise in house prices, comparable to that in other advanced economies, is largely explained by structural supply shortages. Thus, the household sector as a whole does not constitute a significant risk to the banks. Corporate borrowing from banks has been declining for sometime, reflecting falling private investment, and corporate ability to service debt has improved. The tier 1 capital of the major banks has continued to increase and, at just over 7 percent, is regarded as satisfactory by the authorities. All in all, risks in the financial system appear well contained and the supervisory authorities are alert to signs of any emerging imbalances that might pose new risks.

\section{B. Fiscal Policy and the Fiscal Framework}

\section{The structural fiscal surplus target and the expenditure ceilings continue to be} the key pillars of the authorities' fiscal strategy, despite recent strains. While conceding that on present projections, the structural surplus of the general government was not likely to reach the target of 2 percent before 2007 at the earliest, officials did not see this as damaging to the credibility of policy. Officials were at pains to underscore that Sweden's fiscal target was considerably more ambitious than set by the EU countries within the framework of the

${ }^{5}$ The Riksbank, Financial Stability Report, 2004:1. 
Stability and Growth Pact (SGP). Viewed in this light, Sweden's recent fiscal performance, while falling short of the goals of its own framework, was not unsatisfactory. The mission argued that the average fiscal performance in the EU was not necessarily an appropriate benchmark and that Sweden's own well-considered fiscal framework - which would provide a cushion for the future demographic impact on the public welfare systems while providing ample room for maneuver in the event of downturns - should remain the touchstone for assessing fiscal conduct. It was also important to note that the Swedish model of a generous welfare state based on public provision of services implied the need for healthier public finances than in countries with a greater role for private provision.

\section{The margins under the central government expenditure ceilings have been} exhausted as they have been used largely for discretionary spending. In the past two years, the authorities have had to resort to a variety of ad hoc measures - such as shifting expenditures between years and increasing use of tax expenditures - in order to keep within the ceilings. Officials conceded that the ceilings were under continuous strain in a climate of relatively slow growth, rising demand for healthcare, childcare and education, and the government's emphasis on social programs. The budgetary outlook for 2004 was indicative of these pressures.

\begin{tabular}{|c|c|c|c|c|c|c|}
\hline \multicolumn{7}{|c|}{$\begin{array}{l}\text { Central Government Expenditure and Ceilings } \\
\text { (in billions of kronor) }\end{array}$} \\
\hline & 2001 & 2002 & 2003 & $\begin{array}{l}2004 \\
\text { proj. }\end{array}$ & $\begin{array}{l}2005 \\
\text { proj. }\end{array}$ & $\begin{array}{l}2006 \\
\text { proj }\end{array}$ \\
\hline Expenditure subject to ceilings & 786 & 812 & 822 & 856 & 892 & 907 \\
\hline Ceilings & 791 & 812 & 822 & 856 & 894 & 931 \\
\hline Margins & 5 & 0 & 0 & 0 & 2 & 24 \\
\hline in percent of GDP & 0.2 & 0.0 & 0.0 & 0.0 & 0.1 & 0.9 \\
\hline
\end{tabular}

The main risks to the expenditure projections in the Spring budget stemmed from the possibility of a smaller decline in sickness absence than the projected fall of 18 percent and a delayed pick-up in employment. Officials nevertheless underlined the government's firm commitment to the expenditure ceilings as the key instrument for restraining the growth of spending and as central to maintaining credibility. They were candid in acknowledging that further resort to one-off measures to remain under the ceilings could not be ruled out. The ceilings for 2007, to be set in the next budget, are likely to include margins for cyclical spending, as recommended by the staff.

\section{The prospects for a significant reduction in the tax burden have dimmed}

further. The authorities have reiterated that within the constraints set by the spending priorities, tax cuts could be implemented if they could be afforded. Reflecting this position, the fourth and final step of the program of phased reduction in income taxes has been on hold since 2002. Officials stated that the government intended to implement the remaining step at a time when the fiscal position allowed. The authorities accepted, in principle, the view of the recent report of the Swedish Tax Base Commission that reducing the high rate of marginal tax on labor was desirable to raise labor supply and potential growth. However, the government placed priority on improving the incentive structure of the existing tax-benefit system rather than on reducing taxes. High marginal effective tax rates on domestic savings could be eased and the fairness of the tax system improved by increasing the threshold of the wealth tax and reducing exemptions. In the mission's view, raising corporate taxation to 
make up for revenue losses from lowering or abolishing the wealth tax would, however, adversely affect investment and be contrary to international trends. ${ }^{6}$

\section{Finances of the local authorities, responsible for the provision of the bulk of} public services, continue to be strained (Box 1). Officials noted that the pressures on local spending reflected demographic changes and the central government's policy priorities. Constrained by the balanced budget rule, many municipalities and county councils have tried to cut costs. Nevertheless, at times facing underfunded mandates, municipalities have raised local income taxes in recent years. The rising tax rates of local authorities have partially offset the tax cuts implemented at the central government level. The authorities are considering various ways of improving coordination between the central and local levels of government such as by requiring local authorities to specify more clearly their medium-term plans. Options that would reduce uncertainty regarding the amounts of central grants available to local authorities are also being explored.

\section{Sweden is in a relatively favorable position to meet its long-term demographic}

challenges. Gross public debt is at a moderate level and the debt position appears sustainable (Table 5). The reforms implemented in 1999 have placed the public pension system on a sound financial footing in response to the expected sharp rise in the dependency ratio. These reforms introduced an automatic balancing mechanism in the system in order to ensure longterm actuarial balance. However, Sweden's spending on health and long-term care - at around 9 percent of GDP, already among the highest in the EU-is projected to rise to over 12 percent of GDP in 2050, well above the EU average. The planned build-up of assets over the coming years which can later be drawn down as other age-related spending rises, rests critically on meeting the target for general government surplus. ${ }^{7}$ Continued slippages in adhering to the target could put long-term fiscal sustainability at risk.

\footnotetext{
${ }^{6}$ Estimates of assets held abroad to evade taxation range widely between 2 to 10 percent of GDP. Cutting or abolishing the wealth tax would reduce incentives for outflows, but the quantitative impact on net inflows is uncertain.

${ }^{7}$ Under a recent Eurostat ruling, which is currently under discussion with the Swedish authorities, the surpluses of the pension system, amounting to 1 percent of GDP, would be excluded from the general government accounts. Implementation of the ruling would have important implications for the general government surplus target.
} 


\section{Box 1. Local Government and the Tax Burden}

\section{Sweden's large and highly decentralized government sector is facing increasing financial} strains. These strains are manifest in the rising spending pressures on local governments. Facing a balanced budget requirement since 2000 , local authorities have resorted to raising local income tax rates (text figure). Local income tax revenue is large - in the order of 16 percent of GDP — and recent tax increases have eliminated about one quarter of the income tax relief granted by the central government. In a selected issues paper accompanying this report, the staff has tried to assess Sweden's local public finances from an international perspective, and empirically explored various explanations for the gradual increase in local tax rates.

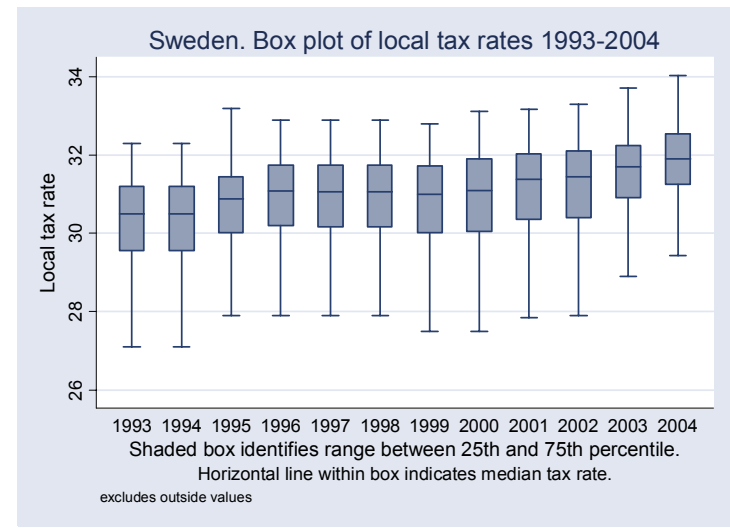

Sweden has a long tradition of extensive local self-government. Like other Nordic countries, local expenditures exceed 40 percent of general government spending with two thirds of it financed from local income tax. Sweden stands out with greater local responsibilities in demographically sensitive areas and an exceptionally high degree of local tax policy autonomy. In addition to education and childcare, local spending is strongly tilted towards health and long-term care, which is sensitive to population aging. Tax policy autonomy is embedded in the constitution and allows local governments to autonomously set local tax rates.

Rising per capita outlays for health and long-tem care services have been a driving factor behind local tax rate increases. Econometric analysis of municipal tax rate increases shows that both higher expenses on long-term care as well as population aging have contributed to a rise in tax rates. Wider local tax bases and higher vertical grants could help alleviate this trend. Looking forward, demographic shifts will likely put additional pressures on local governments - despite lower childcare and education needs in the medium-term - making further tax rate increases probable.

Better control over aggregate tax policy would require improved vertical policy coordination, more predictable local financing sources, and the use of incentives to stick to agreed targets. Sweden's reliance on a balanced budget rule for local authorities may have distracted efforts to develop a more integrated approach of intergovernmental fiscal planning. Budgets of local and central government are drafted in parallel with little exchange on common tax policy objectives. Effective medium-term planning at the local level is hindered by uncertainties about volatile tax revenue and by frequent modifications of central grants. Experience in Denmark and Austria shows that many of these shortcomings can be addressed through a formalized budget preparation process, in which local and central government reach agreement over medium-term expenditure targets, tax rates, and vertical grants. An important element would be high public visibility and transparency of agreed targets to heighten public accountability. 


\section{Structural Policies and Other Issues}

21. While conceding that a faster pace of reforms might be desirable, the authorities viewed their record of structural reform as among the best in the $\mathbf{E U}$. It was noted that Sweden ranked high in various structural indicators of progress under the Lisbon strategy annually prepared by the European Commission - notably in key areas such as public finances, employment, labor force participation among older workers, investment in research and development, and progress towards the Kyoto targets for greenhouse gas emissions. The mission also found commendable Sweden's success in building social cohesion and promoting knowledge-intensive activities. The authorities agreed that, notwithstanding these achievements, scope for progress existed in areas such as reducing sickness absence, promoting greater competition in product markets and improving the functioning of labor markets.

\section{The key structural challenge over the long-term is how to encourage greater} effective labor supply. The working age population is projected to grow very slowly over the coming five decades, with the entire rise of 5 percent ( 0.1 percent per year) due to immigration. The effective supply of labor is expected to fall as a result of the aging of the native-born population, low labor participation rates among immigrants, and falling average working hours. Given the potentially growing importance of the foreign-born population to labor force growth, officials stressed the importance of efforts to enhance the economic integration of immigrants. It was noted in this context that Sweden is one of the few EU countries not to have imposed any special transition rules governing the right of access to its labor market for citizens from the ten new member states. This decision was consistent with Sweden's traditional liberal approach to immigration. In the mission's view, easing the high wage compression would facilitate the absorption of low-skilled immigrants into the labor force. Noting the declining trend of youth participation, the mission also pointed to the need to review the incentive structure in the education system to encourage entry into the workforce at a younger average age.

\section{The high incidence of sickness absence continues to be a major hindrance to} raising effective labor supply (Box 2). Despite some leveling off in sickness absence last year, the rate of sickness absence remained high. Officials did not dispute the mission's view that the high sickness absence in Sweden is explained not only by the high labor force participation of older persons but also by the generosity of the benefit regime. They noted that employers would be sharing more of the cost of sick leave, having to finance 15 percent of the cost of sickness absence after the first two weeks of sickness. Officials explained that the marginal cut in the replacement rate for sickness introduced last year was strictly a reflection of budgetary stringency and was not intended to influence incentives. The reduction will be reversed from 2005 and officials saw no prospect of lowering sickness benefits. However, the authorities intended to tighten the administration of the sickness insurance system with a view to minimizing abuse and misuse. Other measures to reduce sickness absence such as more flexible work arrangements and improved workplace 


\section{Box 2. The Problem of Sickness Absence}

The incidence of sickness absence in Sweden is among the highest in Europe and has risen sharply in recent years. The rate of sickness absence was 5.2 percent in Sweden on average over the period 1995-2003. Possibly reflecting high participation of women, the absence rate was 7 percent for female workers in the same period. Including people on disability pension, almost 15 percent of the working age population was away from work in 2003.

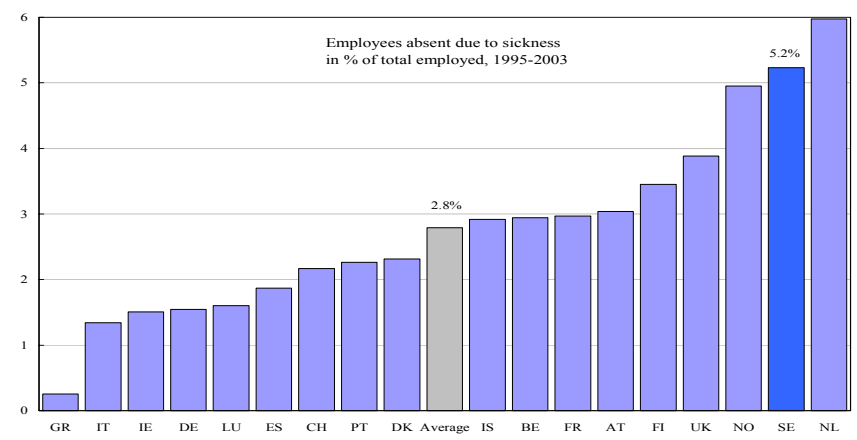

The costs of sickness absence and disability retirement are substantial, not only in terms of the public finances, but also in terms of labor supply and potential growth. Sickness-related public transfers, including disability pensions, amounted to 4.6 percent of GDP in 2003. In 1990-99, sickness benefits averaged 1.4 percent of GDP, second only to the Netherlands in the OECD. Employers currently pay sick benefit at 80 percent of wages for the first 20 days of illness. Costs in terms of forgone output, even though highly uncertain, are likely to be substantial. With the expected negative impact of demographics and declining work effort, containing work absence is also crucial as part of a strategy aimed at stimulating labor supply.

High sickness absence is a recurring problem in Sweden and has motivated various attempts to modify the generous public insurance system (Figure 7). Since 1997 sickness absence has risen sharply to a recent peak, prompting the government to set the goal of halving sickness absence between 2002 and 2008. Recently, while cases of sick leave declined, the duration of sickness absence has increased, reflected in a surge in the number of people receiving sickness compensation. Most recent initiatives are aimed at increasing responsibilities of all parties involved with a strong emphasis on ensuring fast rehabilitation. However, at the same time, the employer's obligation period will be cut to first two weeks of sickness absence and the compensation rate will be slightly raised, making the overall incentive impact of the new reform measures ambiguous.

The high sickness absence in Sweden cannot be entirely explained by high participation rates. A staff study (see Selected Issues Paper) finds that participation rates and demographic factors cannot fully account for the observed absence rates within a panel of European countries. Generosity of the sickness insurance system, working time arrangements (contractual hours and flexible hours of work), and cyclical effects play a decisive role, too. Even when controlling for these factors, absence rate in Sweden - supporting earlier empirical evidence-remains distinct as manifested by a significant impact of Sweden-specific participation rate, sickness benefits, and unemployment gap. The study also underscores the importance of interactions of the sickness insurance system with labor market institutions, in particular unemployment insurance and employment protection. Reducing contractual hours may not be inconsistent with policies to reduce absence, though the impact of working time reduction may depend also on the availability of flexible working arrangements. 
environment were also expected to help ease the problem. The mission argued that reducing the replacement rate would need to be a key element of any package of measures designed to achieve the authorities' goal of reducing sickness absence to half its 2002 level by 2008.

\section{The authorities agreed that the tax-benefit system had important disincentive} effects on labor supply. Officials felt, however, that these effects had been mitigated by the recent income tax cuts, and should be seen in the larger context of a system which also provided many positive incentives. For instance, public spending on child care and care of the elderly helped promote high female participation. Officials agreed that the incentives were also greatly influenced by the interaction of various social welfare programs and labor market institutions and a systematic evaluation of these complex interactions was necessary to fashion an effective policy response.

\section{There was agreement on the need to strengthen competition in product markets.} Although competition had increased substantially in the past decade, barriers to competition are still significant, especially in the construction, pharmaceuticals and retail trade sectors, and the Swedish price level remained significantly above the EU average. The authorities have been considering ways to encourage greater competition between public and private sectors in the provision of public services. Officials conceded that administrative controls on rent-setting and the large public ownership of housing, particularly in the rental sector, may be inhibiting the development of an efficient rental market. The lack of a properly functioning housing market has also depressed housing investment and tended to hamper labor mobility. Nevertheless, officials saw little prospect of significant deregulation of rental housing because such a step was seen as contrary to the overriding objective of ensuring affordable housing to everyone.

26. The Swedish government is playing a positive role in the efforts to revitalize the Doha Development Agenda. The authorities strongly support elimination of subsidies to farm exports and substantial reduction of domestic support to agriculture in the advanced countries. They continue to advocate liberal access to exports from low-income developing countries. At 0.7 percent of GNP, Sweden's official development assistance remains one of the highest in the world.

\section{Staff Appraisal}

27. Sweden's economic performance over the past decade has been impressive, especially in the comparative context of the European Union. Along with satisfactory growth and macroeconomic stability, the latter grounded in the framework of fiscal rules and an inflation targeting framework that has garnered high credibility, Sweden has made important strides in preparing for the coming demographic transition. Notably, reforms have been implemented to place the public pension system on a sound financial footing. With a leading role in knowledge-intensive activities, the economy is well positioned to reap the fruits of technological advances. 
28. The economy weathered the global downturn relatively well. A notable feature of recent growth has been a strong rise in productivity, helping to bring inflation well under the target of 2 percent. The mirror image of the rise in productivity has, however, been a continuing fall in employment and sharply rising unemployment, both open and latent. Looking beyond the cyclical recovery expected in the near term, Sweden should be well positioned to build on its recent successes by reviving the agenda for structural reform which has lost momentum in the last couple of years.

29. The waning pace of structural reforms is a cause for concern. The relatively benign economic outlook and the parliamentary election calendar would suggest that this is an opportune moment for addressing the unfinished task of further streamlining the Swedish welfare state. Indeed, in the aftermath of the referendum on the euro late last year, the government launched a public discussion on how to promote growth, but so far without a concrete program of action. As the European Union expands and global economic integration gathers pace, it is critical for Sweden not to miss this window of opportunity to enhance its long-term prospects for growth and welfare.

30. With inflation projected to be below target over the next two years, a policy of keeping rates on hold for the near term would be appropriate. As the restraining impact of domestic influences recedes over time and upside risks from the projected upturn at home and abroad begin to predominate, inflation is expected to rise gradually. The policy rate would accordingly need to be raised in due course. To the extent that the fiscal stance is insufficiently restrictive as the recovery gathers speed, monetary policy would need to be tightened earlier rather than later.

\section{The Riksbank's conduct of monetary policy and its success in achieving the} inflation target have earned it high credibility, although there may still be room for clearer communication. The outcome of the recent round of wage negotiations testifies to the Riksbank's ability to guide expectations. However, it appears that the Riksbank has not always succeeded in communicating clearly its message to the markets, resulting on occasion in some confusion about the target variable and horizon. There may be room for refining the communication strategy by being more explicit about the role of judgment in assessments and extending the forecast horizon beyond two years.

\section{Safeguarding the fiscal surplus target of two percent of GDP over the business} cycle is central to maintain confidence in Sweden's medium-term fiscal framework. Although the framework has a good track record and Sweden's position remains favorable in a comparative EU context, efforts to attain the target for the general government have slackened in the recent past. Over time, this gradual weakening could raise concerns about fiscal discipline and begin to undermine the fiscal framework that has served to anchor macroeconomic stability. A more ambitious fiscal adjustment in 2005-06 through forceful measures to rein in public spending would serve to demonstrate the authorities' commitment to achieve the target. 
33. The authorities should adhere strictly to the expenditure ceilings and ensure that margins are restricted to cyclical spending. The ceilings have no margins left for error this year and there are signs that spending on sickness and disability benefits will not slow down as much as expected. A coherent medium-term plan is needed to contain public spending without resorting to ad hoc steps such as shifting expenditure between years and additional tax expenditures.

\section{The scope for tax cuts has narrowed further even as they are needed to provide} impetus to work effort and saving. The tax burden of the general government, already one of the highest in the world, is likely to rise further as local governments try to balance their budgets. As international competition over tax bases intensifies, a review of the complex capital tax system, encompassing taxation of wealth, inheritance, and gifts, is warranted.

\section{The rising tax burden is, in part, a reflection of insufficient policy coordination} between central and local governments. The intention to encourage local authorities to specify more clearly their medium-term spending plans could go some way towards improving fiscal coordination. The use of balancing grants from the central government would help smooth fluctuations in local revenue and prevent procyclical increases in tax rates.

36. The financial system remains sound. Bank profitability has improved and capital adequacy and loss provision remain at satisfactory levels. Although household debt has kept rising, low interest expenses and higher home values serve to considerably mitigate its burden. All in all, credit risks appear well contained, although those associated with a significant decline in property values or a rise in interest rates bear careful monitoring.

\section{A decisive reform of the tax-benefit regime is necessary to improve incentives,} raise potential growth, and ease fiscal pressures. Cutbacks in entitlements, coupled with a reduction in the high tax burden on labor, would help encourage greater effective labor supply in the face of population ageing and the sharp fall in hours worked. Sizeable steps in this direction are required to realize the authorities' ambitious labor market and social policy objectives such as the target of 80-percent employment rate and the goals of halving the number of people on social assistance and sickness leave. High wage compression and generous social benefits continue to impede an efficient use of labor resources. Overall, underlying trends in labor supply signal a need for more fundamental policy reforms rather than short-term palliatives.

38. Efficient use of human resources is imperative for long-term sustainability of the Swedish model. As the main source of labor supply over the coming years is expected to be the foreign-born population, better integration of immigrants into the labor force is crucial. At the same time, the incentive structure in the education system could be re-assessed to help reverse the declining trend of youth participation. The role of incentives in sickness absence warrants a better recognition. In this context, the decision to reverse the small reduction in the replacement rate of sickness benefits introduced last year is clearly unhelpful. 
39. Strengthening competition in product markets is a necessary component of the agenda for growth. Reducing rigidities that continue to impair the functioning of product markets would raise consumer welfare and could have positive spillover effects on the labor market. With controls on rent-setting inhibiting the development of an efficient rental market, there is room to move towards a more market-oriented approach that would preserve social policy objectives. Internationally, Sweden's advocacy of liberal trade policies serves to complement well its commendable record of generous development assistance.

40. The authorities deserve to be commended for their high level of official development assistance.

41. Sweden's provision of economic statistics is adequate for the purpose of Fund surveillance.

42. Sweden is expected to remain on the standard 12-month consultation cycle. 
Figure 1. Sweden: Output Developments and Prospects

(Annual percentage change)

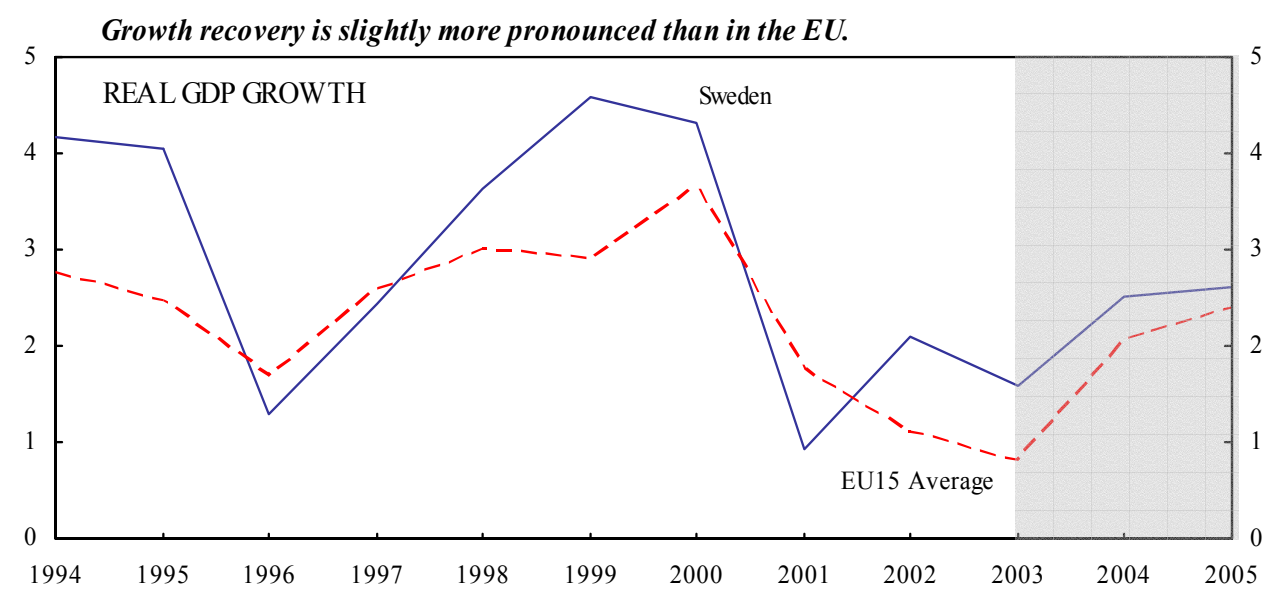

With a stable contribution from net external demand...
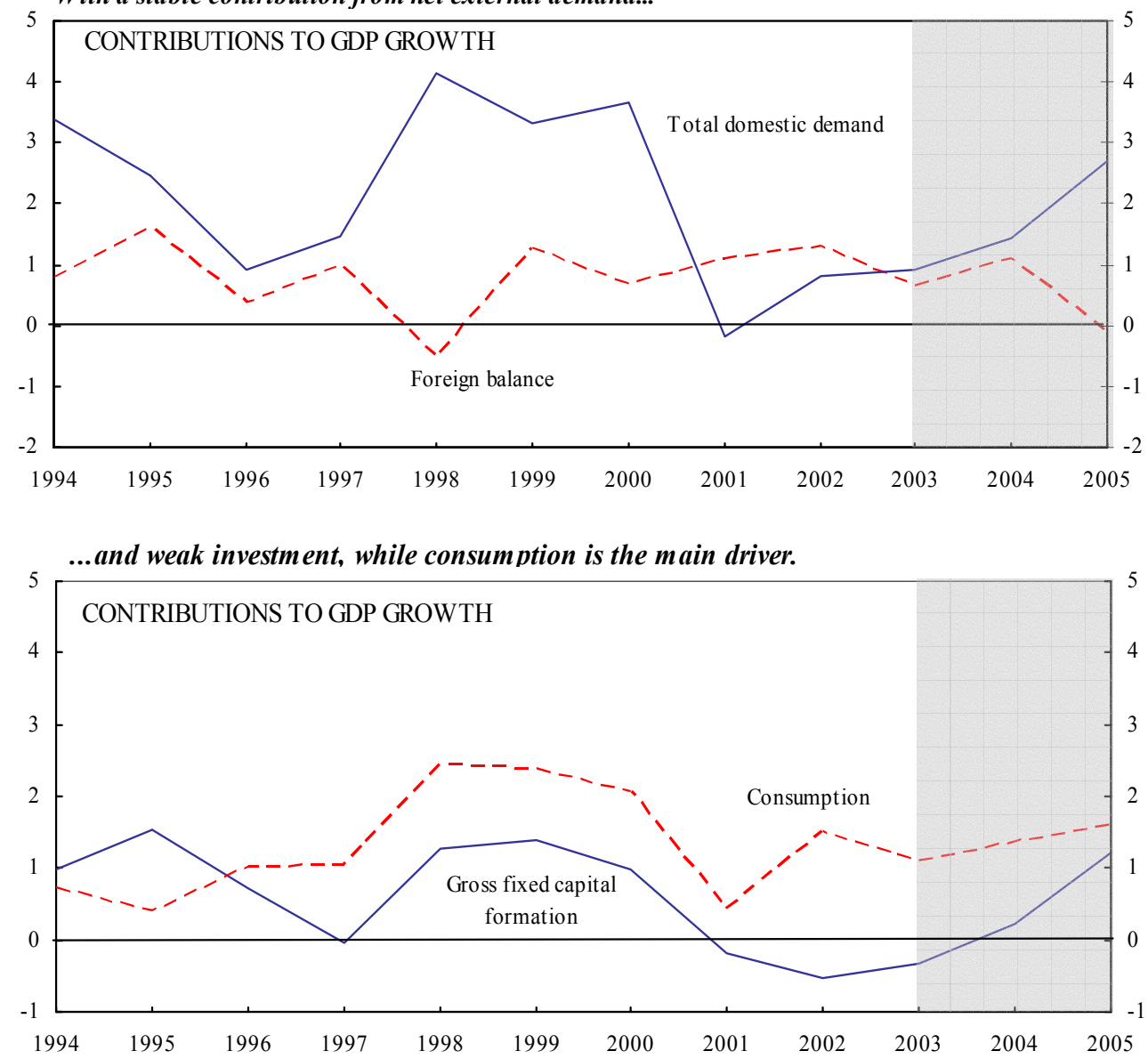

Sources: Statistics Sweden; and staff projections. 
Figure 2. Sweden: Labor Market Developments

Participation is stable...

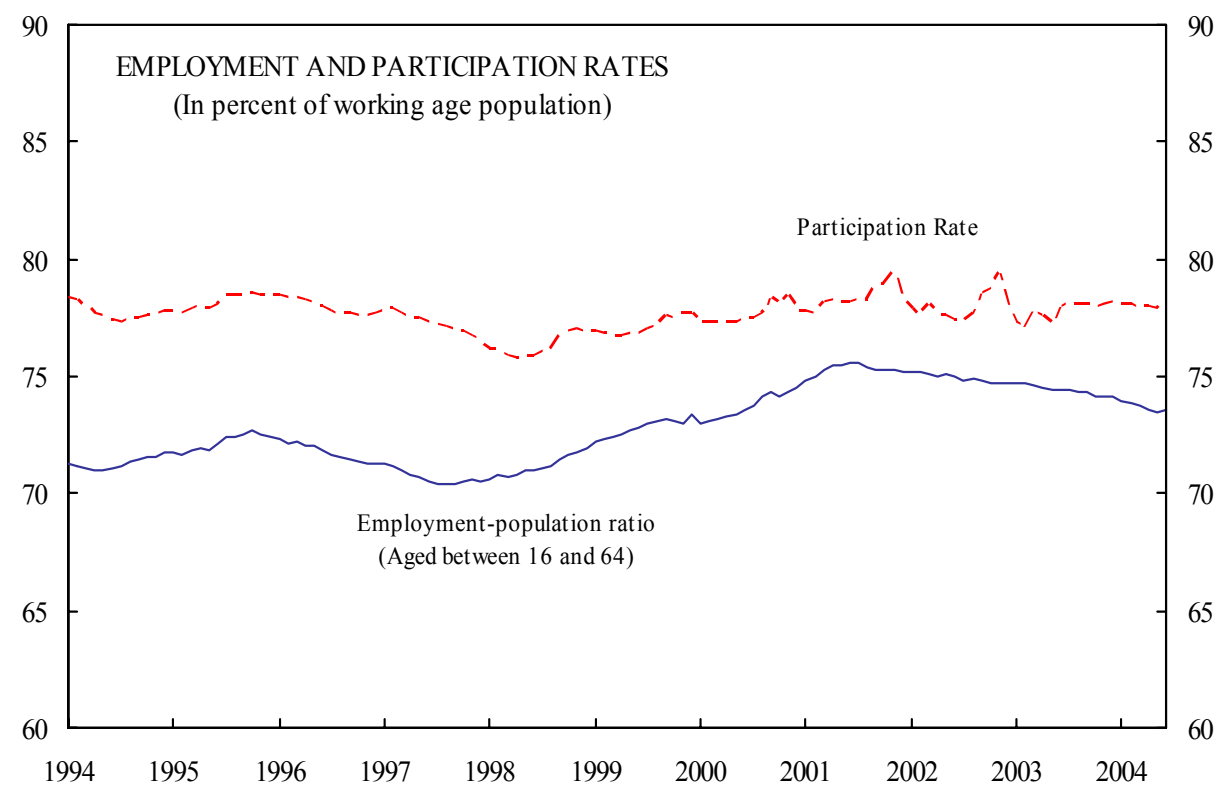

...while unemployment has been rising.

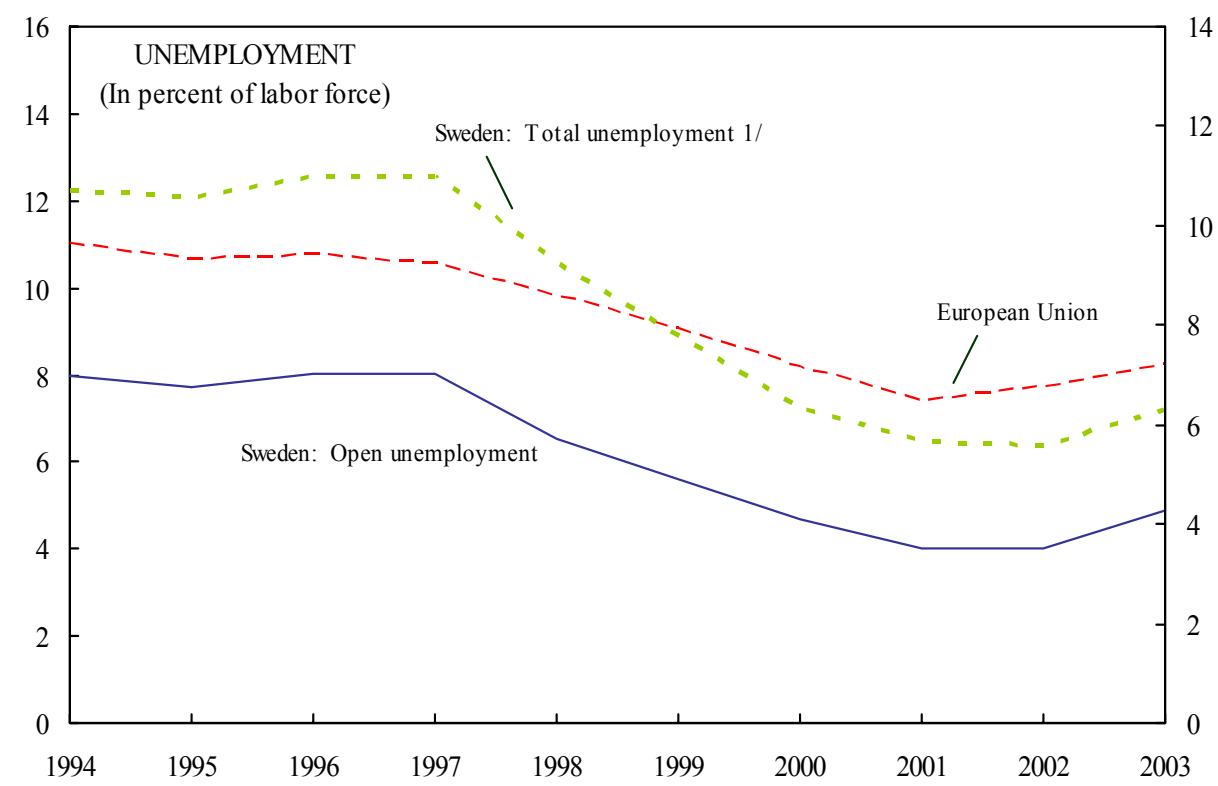

Sources: Statistics Sweden and OECD.

1/ Open unemployment plus participants in active labor market programs that are excluded from open unemployment (e.g., retraining, and youth employment schemes).

\section{CInternational Monetary Fund. Not for Redistribution}


Figure 3. Sweden: Inflation Developments

(Percent change from a year ago)

Headline inflation is declining...

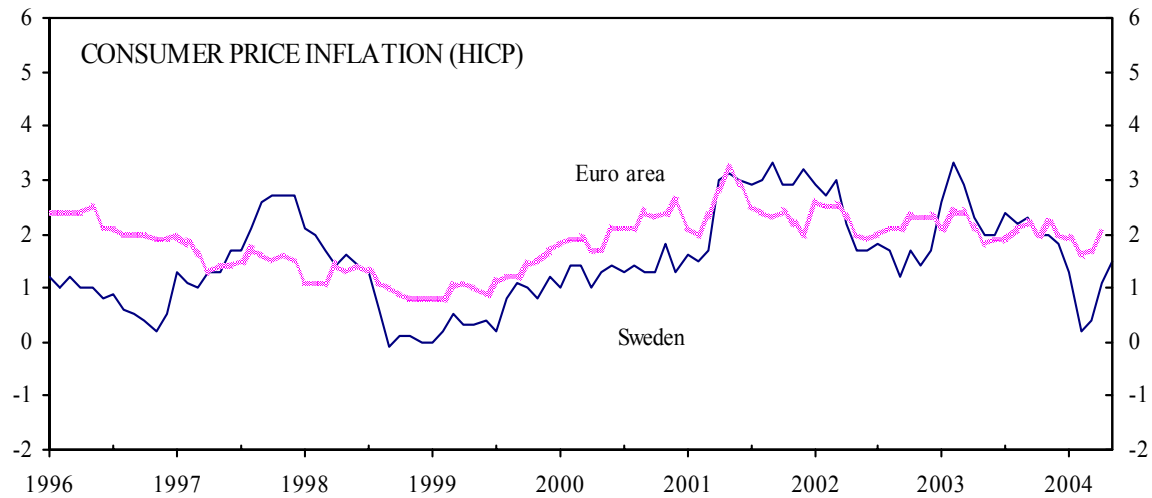

...and underlying inflation declines...

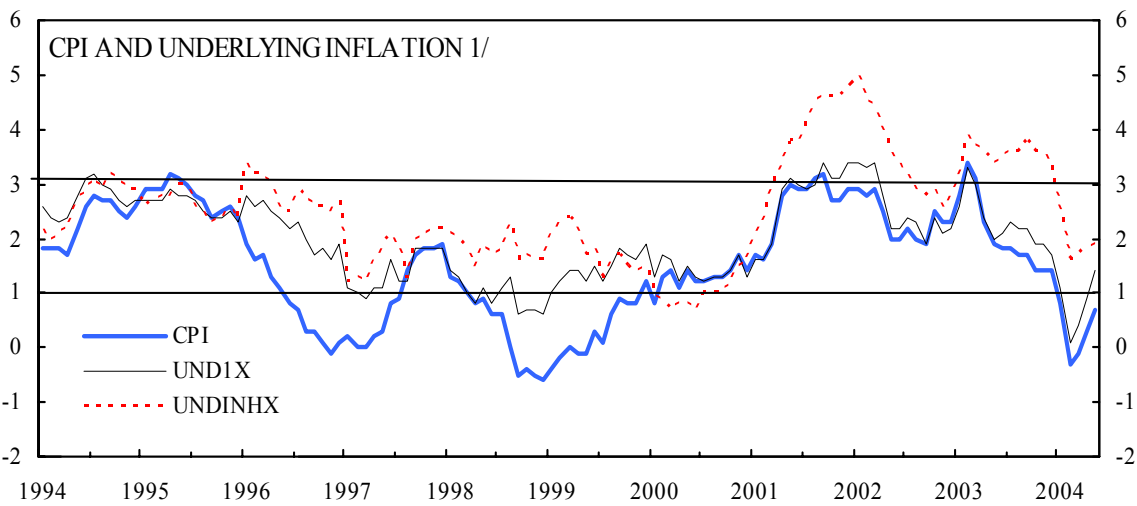

...while expectations are edging down slightly.

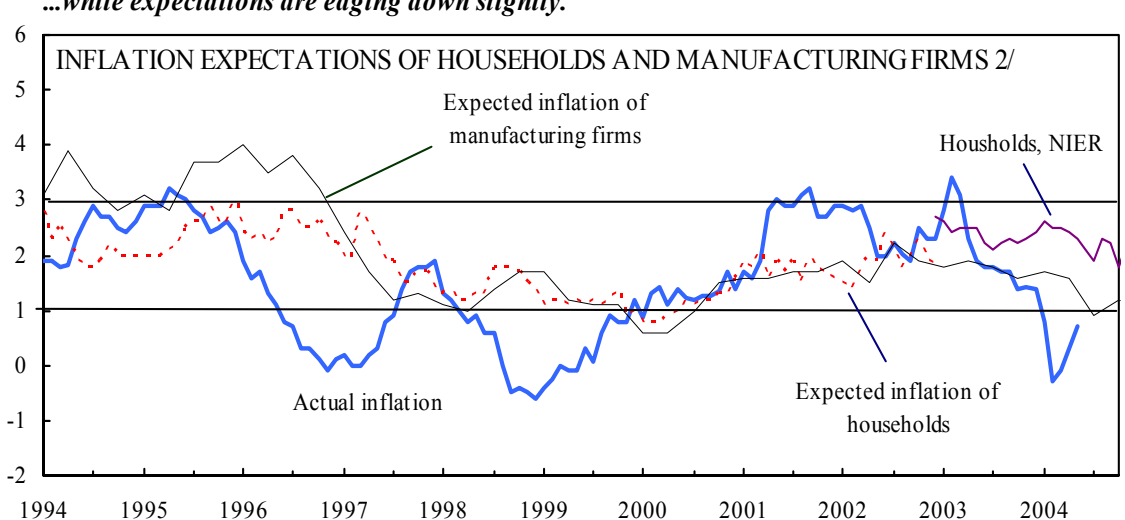

Sources: Statistics Sweden and the Riksbank.

1/ UND1X = CPI excluding changes in indirect taxes and subsidies and interest costs for owneroccupied housing; UNDINHX also excludes changes in import prices; the horizontal lines indicate a 1 percent range around the 2 percent inflation target.

2/ Inflation expected one year ahead.

\section{CInternational Monetary Fund. Not for Redistribution}


Figure 4. Sweden: Exchange Rate Developments
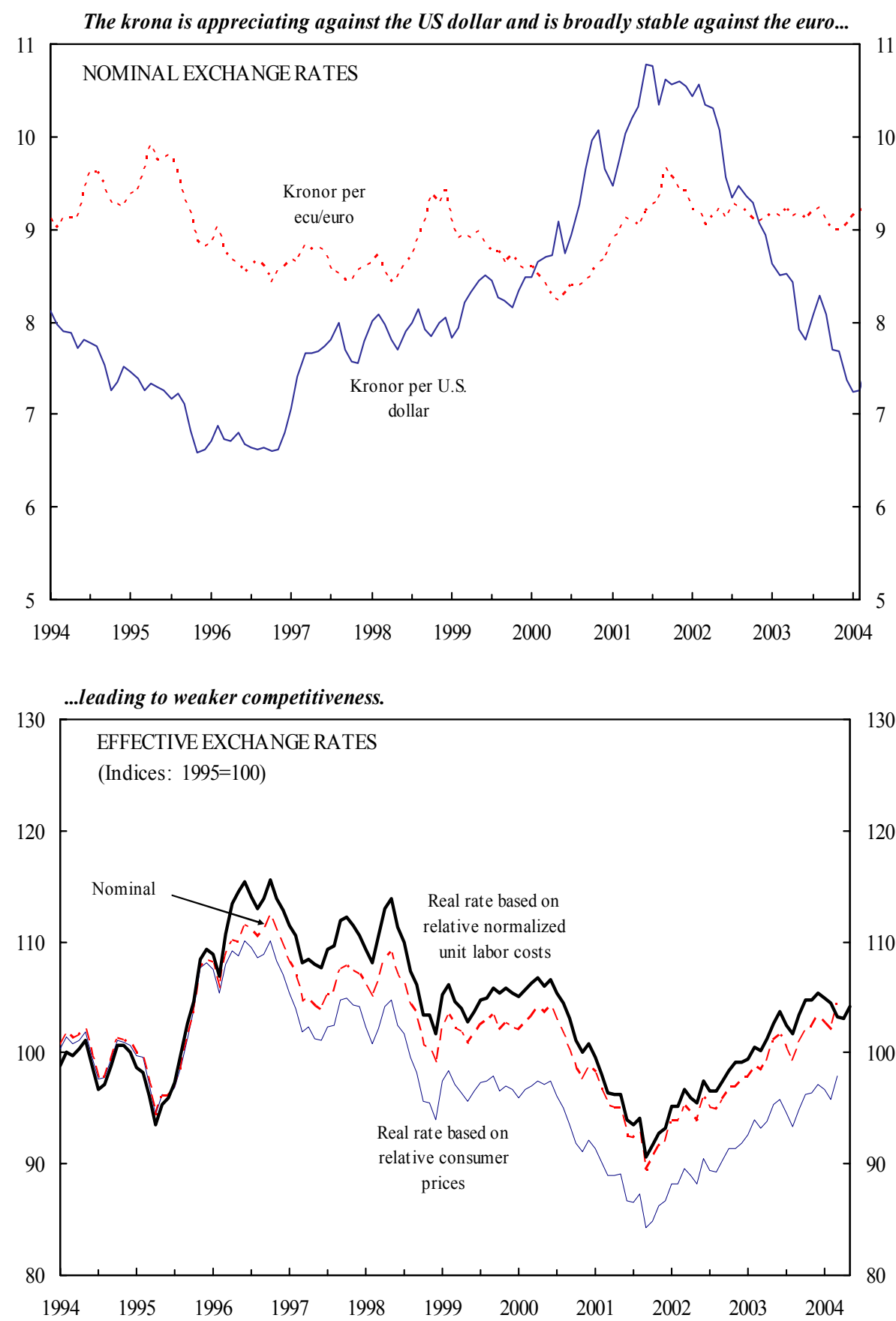

Source: IMF, International Financial Statistics 
Figure 5. Sweden: Asset Price and Interest Rate Developments

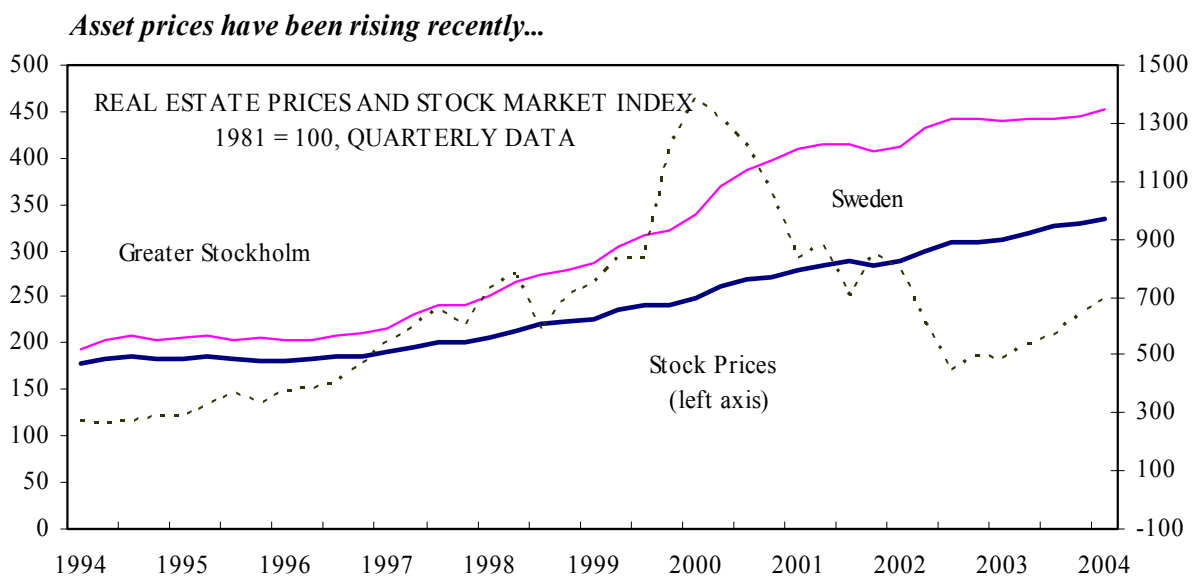

...while nominal interest rates have declined...

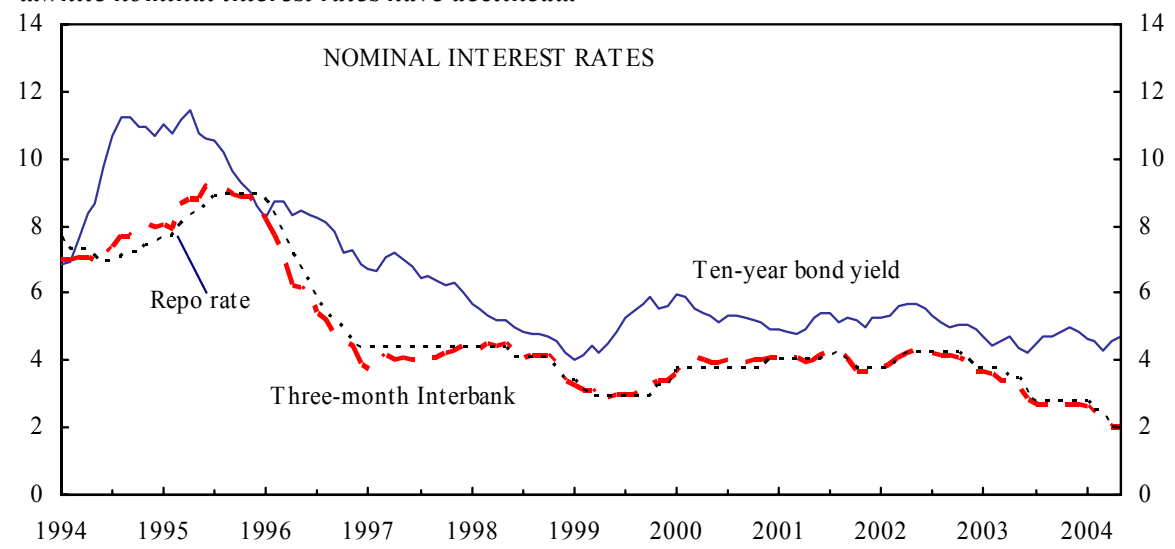

...but less than in the euro area.

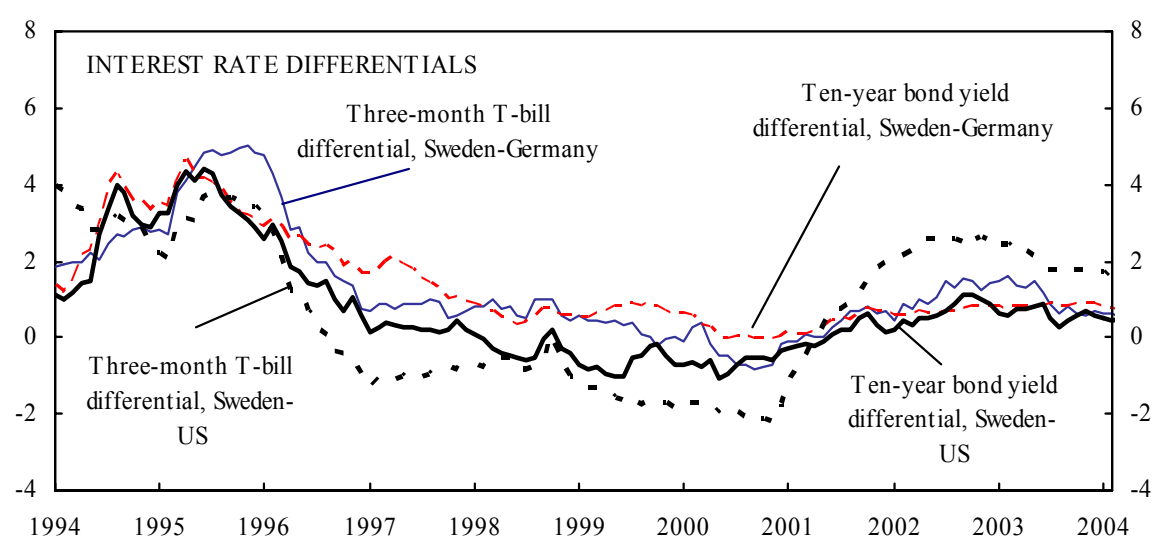

Sources: Statistics Sweden; Riksbank; IMF, International Financial Statistics, and INS.

\section{CInternational Monetary Fund. Not for Redistribution}


Figure 6. Sweden: Fiscal Developments and Prospects

(In percent of GDP)

While the trend decline in expenditures has come to an end...
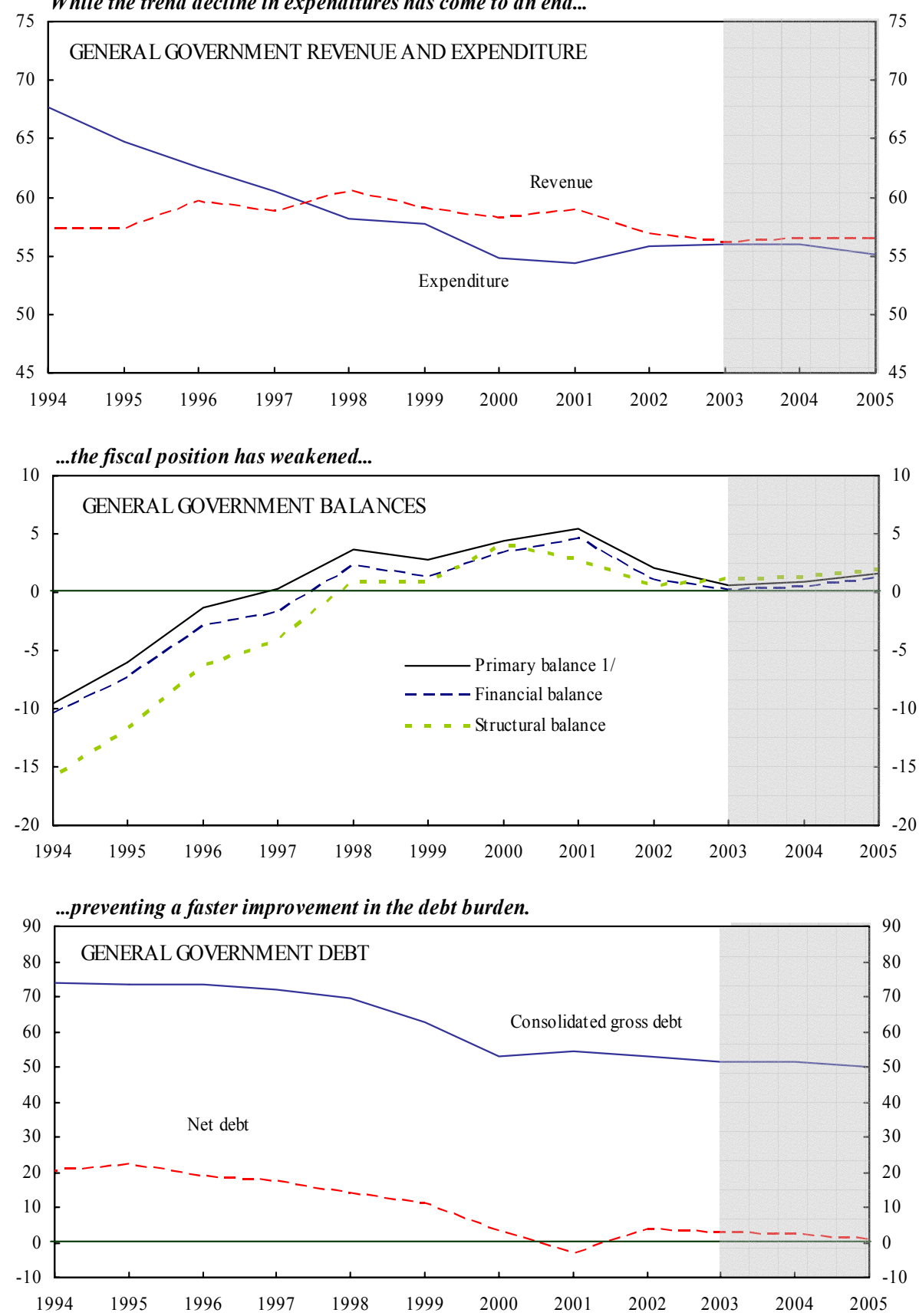

Sources: Statistics Sweden and Ministry of Finance.

1/ Excluding interest expenditure and income. 
Figure 7. Sweden: Sick Leave and Main Changes in Sickness Compensation System

Increasing generosity of sickness compensation system has been associated with a surge in sick leave days

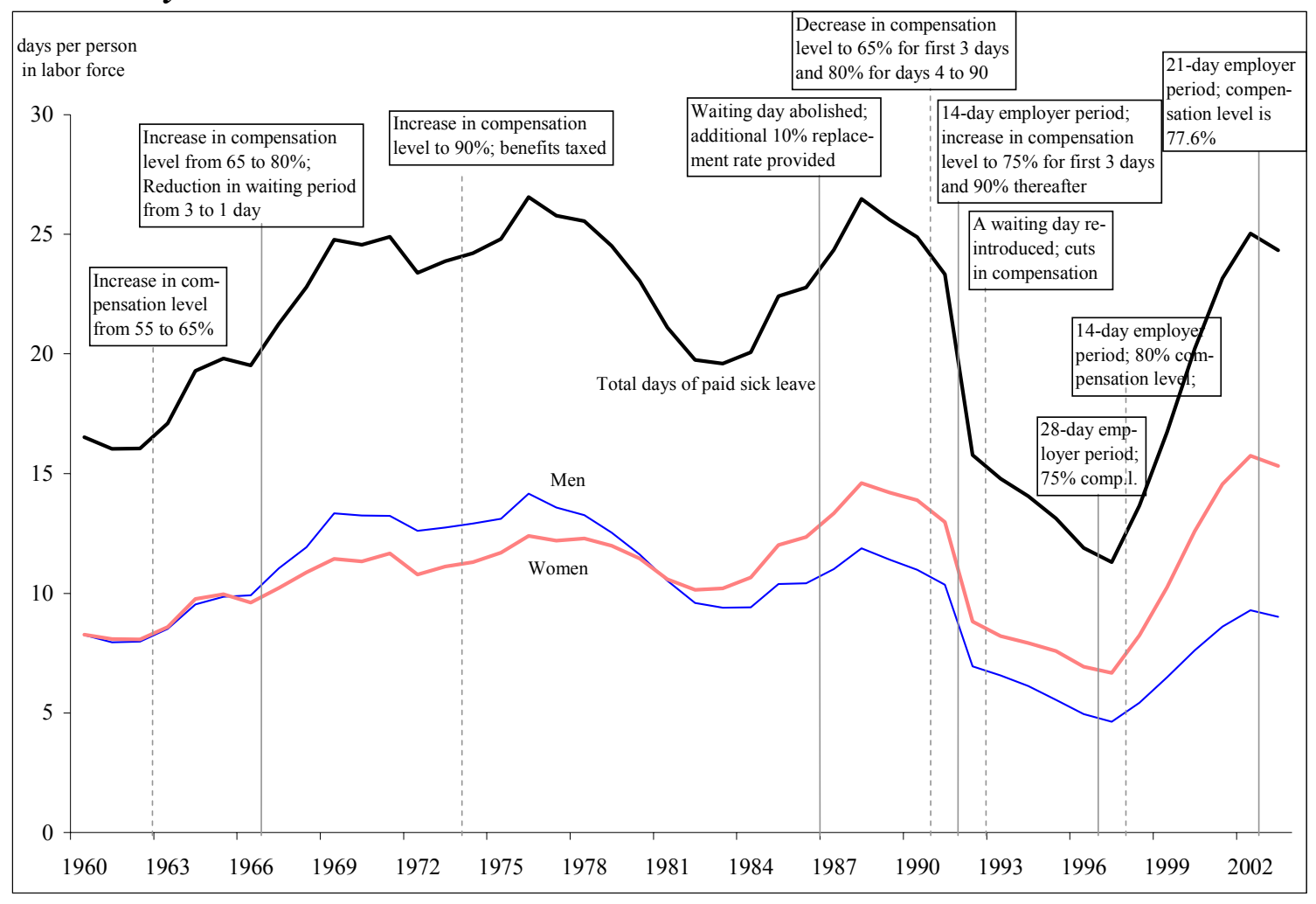

Sources: National Social Insurance Board (RFV), Andrén (2003), Henrekson and Persson (2004), Social Security Programs Throughout the World, and EIRO 
Table 1. Sweden: Selected Economic Indicators

\begin{tabular}{|c|c|c|c|c|c|c|c|c|}
\hline & 1998 & 1999 & 2000 & 2001 & 2002 & 2003 & $20041 /$ & $\begin{array}{c}\text { Average } \\
2005-071 /\end{array}$ \\
\hline \multicolumn{9}{|l|}{ Real economy (in percent change) } \\
\hline Real GDP & 3.6 & 4.6 & 4.3 & 0.9 & 2.1 & 1.6 & 2.5 & 2.5 \\
\hline Domestic Demand & 4.4 & 3.5 & 3.9 & -0.2 & 0.9 & 1.0 & 1.6 & 2.2 \\
\hline CPI $2 /$ & 1.0 & 0.6 & 1.3 & 2.7 & 2.0 & 2.3 & 0.7 & 2.0 \\
\hline Open unemployment rate (in percent) & 6.5 & 5.6 & 4.7 & 4.0 & 4.0 & 4.9 & 5.5 & 4.8 \\
\hline Participation in labor market programs (in percent) & 4.1 & 3.3 & 2.6 & 2.5 & 2.6 & 2.1 & 2.3 & 2.0 \\
\hline Gross national saving (percent of GDP) & 21.1 & 21.8 & 22.6 & 22.2 & 22.1 & 22.1 & 21.6 & 21.0 \\
\hline Gross domestic investment (percent of GDP) & 17.2 & 17.5 & 18.5 & 17.7 & 16.8 & 15.8 & 15.2 & 15.5 \\
\hline \multicolumn{9}{|l|}{ Public finance (in percent of GDP) } \\
\hline General government balance & 1.9 & 2.3 & 5.1 & 2.9 & -0.3 & 0.5 & 0.3 & 0.9 \\
\hline Structural balance $3 /$ & -0.9 & 0.5 & 3.8 & 3.0 & -0.2 & 1.1 & 1.2 & 1.5 \\
\hline General government debt & 69.4 & 62.7 & 52.8 & 54.4 & 52.6 & 51.9 & 52.1 & 50.7 \\
\hline \multicolumn{9}{|l|}{ Money and credit (12-month, percent change) } \\
\hline M0 & 5.1 & 11.9 & 2.0 & 8.8 & -0.9 & 2.7 & $\ldots$ & $\ldots$ \\
\hline M3 & 2.5 & 9.7 & 2.8 & 6.7 & 4.5 & 3.1 & $\ldots$ & $\ldots$ \\
\hline Credit to non-bank public & 6.9 & 5.6 & 9.1 & 8.8 & 4.2 & 2.7 & $\ldots$ & $\cdots$ \\
\hline \multicolumn{9}{|l|}{ Interest rates (year average) } \\
\hline Three-month interbank rate & 4.9 & 3.6 & 3.6 & 4.1 & 3.9 & 3.9 & $\ldots$ & $\ldots$ \\
\hline Ten-year government bond yield & 5.9 & 4.3 & 5.6 & 4.8 & 5.2 & 4.6 & $\cdots$ & $\cdots$ \\
\hline \multicolumn{9}{|l|}{ Balance of payments (in percent of GDP) } \\
\hline Trade balance & 6.2 & 6.2 & 5.7 & 6.2 & 6.9 & 7.0 & 7.5 & 7.7 \\
\hline Current account & 3.9 & 4.3 & 4.1 & 4.4 & 5.4 & 6.4 & 6.4 & 5.6 \\
\hline International reserves (in billions of US dollars) & 16.9 & 18.0 & 16.3 & 14.8 & 19.3 & 22.4 & $\ldots$ & $\ldots$ \\
\hline Reserve cover (months of imports of goods and services) & 2.3 & 2.4 & 2.0 & 2.1 & 2.6 & 2.4 & $\ldots$ & $\ldots$ \\
\hline \multicolumn{9}{|l|}{ Exchange rate (period average, unless otherwise stated) } \\
\hline Exchange rate regime & \multicolumn{3}{|c|}{ Floating exchange rate } & & & & & \\
\hline Present rate (May 31, 2004) & \multicolumn{3}{|c|}{ US\$ $1=$ Skr 7.4515} & & & & & \\
\hline Nominal effective rate $(1995=100)$ & 101.1 & 99.7 & 100.0 & 91.6 & 93.1 & 97.5 & $\ldots$ & $\ldots$ \\
\hline Real effective rate $(1995=100) 4 /$ & 103.8 & 100.6 & 100.0 & 90.8 & 93.0 & 98.3 & $\ldots$ & $\ldots$ \\
\hline
\end{tabular}

Sources: Statistics Sweden; Riksbank; Ministry of Finance; Datastream; INS; and staff estimates.

1/ Staff projections.

2/ Harmonized index of consumer prices.

3/ In percent of potential GDP, also adjusted for one-off effects.

4/ Based on relative normalized unit labor cost in manufacturing. 
Table 2. Sweden: General Government Financial Accounts, 1998-2006

\begin{tabular}{|c|c|c|c|c|c|c|c|c|c|}
\hline & 1998 & 1999 & 2000 & 2001 & 2002 & 2003 & $\begin{array}{l}2004 \\
\text { Proj. }\end{array}$ & $\begin{array}{l}2005 \\
\text { Proj. }\end{array}$ & $\begin{array}{l}2006 \\
\text { Proj. }\end{array}$ \\
\hline & \multicolumn{9}{|c|}{ (in percent of GDP) } \\
\hline Total revenue & 60.1 & 60.1 & 59.8 & 57.2 & 55.4 & 56.1 & 55.9 & 55.5 & 55.4 \\
\hline Primary revenue & 56.0 & 56.7 & 56.6 & 55.0 & 53.2 & 54.0 & 53.7 & 53.4 & 53.3 \\
\hline Tax revenue (incl. charges) & 52.5 & 53.3 & 53.4 & 51.7 & 49.8 & 50.5 & 50.3 & 50.0 & 49.8 \\
\hline Nontax revenue & 3.5 & 3.4 & 3.2 & 3.3 & 3.4 & 3.4 & 3.4 & 3.4 & 3.5 \\
\hline Interest receipts & 4.1 & 3.3 & 3.1 & 2.2 & 2.2 & 2.2 & 2.2 & 2.2 & 2.2 \\
\hline Total expenditure & 58.2 & 57.7 & 54.7 & 54.3 & 55.7 & 55.7 & 55.6 & 55.0 & 54.3 \\
\hline Primary expenditure & 52.7 & 52.9 & 50.6 & 51.1 & 52.5 & 53.5 & 53.2 & 52.5 & 51.8 \\
\hline Transfers & 23.1 & 22.6 & 21.4 & 21.2 & 21.3 & 22.2 & 21.9 & 21.6 & 21.1 \\
\hline Consumption and investment & 29.6 & 30.3 & 29.2 & 29.9 & 31.2 & 31.3 & 31.3 & 30.9 & 30.7 \\
\hline Interest payments & 5.5 & 4.8 & 4.1 & 3.2 & 3.2 & 2.2 & 2.4 & 2.5 & 2.6 \\
\hline Overall balance & 1.9 & 2.3 & 5.1 & 2.9 & -0.3 & 0.5 & 0.3 & 0.6 & 1.1 \\
\hline Central government & 0.5 & 4.2 & 2.7 & 7.6 & -1.7 & -1.4 & -1.7 & -1.8 & -1.1 \\
\hline Pension system & 1.3 & -2.0 & 2.2 & -4.6 & 2.0 & 2.0 & 2.0 & 2.1 & 2.0 \\
\hline Local governments & 0.2 & 0.1 & 0.2 & -0.2 & -0.6 & -0.2 & -0.1 & 0.3 & 0.1 \\
\hline Primary balance & 3.3 & 3.8 & 6.0 & 3.8 & 0.7 & 0.5 & 0.5 & 0.9 & 1.5 \\
\hline \multicolumn{10}{|l|}{ Structural adjustment } \\
\hline Cyclical adjustment & -2.3 & -1.3 & -0.8 & 0.1 & 0.1 & 0.6 & 0.9 & 0.7 & 0.5 \\
\hline Cyclically adjusted overall balance & -0.4 & 1.0 & 4.3 & 3.0 & -0.2 & 1.1 & 1.2 & 1.3 & 1.6 \\
\hline Temporary effects & -0.5 & -0.5 & -0.5 & 0.0 & 0.0 & 0.0 & 0.0 & 0.0 & 0.0 \\
\hline Structural balance & -0.9 & 0.5 & 3.8 & 3.0 & -0.2 & 1.1 & 1.2 & 1.3 & 1.6 \\
\hline Fiscal stimulus & 0.9 & -1.4 & -3.2 & 0.8 & 3.1 & -1.2 & -0.1 & -0.1 & -0.3 \\
\hline \multicolumn{10}{|l|}{ Memorandum items: } \\
\hline Gross public debt (in percent of GDP) & 69.4 & 62.7 & 52.8 & 54.4 & 52.6 & 51.9 & 52.1 & 51.5 & 50.6 \\
\hline Net public debt (in percent of GDP) & 19.9 & 9.3 & 1.3 & -2.9 & 4.8 & 0.1 & -0.3 & -0.6 & -1.6 \\
\hline Nominal GDP (in billion of kronor) & 1,972 & 2,077 & 2,195 & 2,266 & 2,347 & 2,439 & 2,520 & 2,628 & 2,741 \\
\hline Output gap (in percent of potential) & -0.6 & 0.6 & 1.2 & -0.1 & -0.1 & -0.9 & -1.2 & -1.0 & -0.7 \\
\hline
\end{tabular}

Source: Ministry of Finance. 
Table 3. Sweden: Balance of Payments, 1998-2009 (in billions of U.S. dollars)

\begin{tabular}{|c|c|c|c|c|c|c|c|c|c|c|c|c|}
\hline & 1998 & 1999 & 2000 & 2001 & 2002 & 2003 & $\begin{array}{l}2004 \\
\text { proj. }\end{array}$ & $\begin{array}{r}2005 \\
\text { proj. }\end{array}$ & $\begin{array}{l}2006 \\
\text { proj. }\end{array}$ & $\begin{array}{l}2007 \\
\text { proj. }\end{array}$ & $\begin{array}{l}2008 \\
\text { proj. }\end{array}$ & $\begin{array}{r}2009 \\
\text { proj. }\end{array}$ \\
\hline Current account & 9.7 & 10.7 & 9.9 & 9.7 & 13.0 & 19.3 & 21.7 & 19.6 & 20.0 & 21.3 & 22.6 & 24.0 \\
\hline as a percentage of GDP & 3.9 & 4.3 & 4.1 & 4.4 & 5.4 & 6.4 & 6.4 & 5.6 & 5.5 & 5.6 & 5.7 & 5.8 \\
\hline Goods and services & 15.5 & 15.5 & 13.8 & 13.6 & 16.8 & 21.1 & 25.2 & 25.1 & 27.7 & 31.3 & 35.2 & 39.3 \\
\hline Exports of goods and services & 105.5 & 106.9 & 110.7 & 100.2 & 108.4 & 133.1 & 157.0 & 168.5 & 177.4 & 187.8 & 199.1 & 211.0 \\
\hline Goods & 85.8 & 85.2 & 88.3 & 77.5 & 84.3 & 102.2 & 120.0 & 128.2 & 134.3 & 141.4 & 149.3 & 157.4 \\
\hline Services & 19.7 & 21.7 & 22.4 & 22.7 & 24.0 & 30.9 & 37.0 & 40.3 & 43.1 & 46.3 & 49.9 & 53.6 \\
\hline Imports of goods and services & -90.0 & -91.5 & -96.9 & -86.7 & -91.6 & -112.0 & -131.8 & -143.4 & -149.8 & -156.4 & -164.0 & -171.7 \\
\hline Goods & -68.7 & -68.5 & -72.7 & -63.0 & -67.6 & -83.2 & -97.2 & -105.3 & -109.4 & -113.6 & -118.5 & -123.4 \\
\hline Services & -21.3 & -23.0 & -24.2 & -23.6 & -24.0 & -28.8 & -34.5 & -38.1 & -40.4 & -42.8 & -45.5 & -48.3 \\
\hline Income & -3.3 & -2.0 & -1.4 & -1.4 & -1.0 & 0.3 & 0.5 & -1.2 & -3.0 & -5.0 & -7.1 & -9.4 \\
\hline Compensation of employees & -0.3 & -0.3 & -0.3 & -0.3 & -0.2 & -0.2 & -0.3 & -0.3 & -0.4 & -0.4 & -0.4 & -0.4 \\
\hline Investment income & -3.0 & -1.8 & -1.2 & -1.2 & -0.8 & 0.5 & 0.8 & -0.9 & -2.7 & -4.6 & -6.7 & -9.0 \\
\hline Current transfers & -2.6 & -2.7 & -2.4 & -2.4 & -2.8 & -2.1 & -4.1 & -4.3 & -4.7 & -5.0 & -5.4 & -5.8 \\
\hline Official & -2.0 & -2.1 & -2.1 & -2.1 & -2.3 & -1.7 & -3.3 & -3.6 & -3.8 & -4.1 & -4.4 & -4.8 \\
\hline Capital and financial account & -3.2 & -6.6 & -1.0 & -3.0 & -12.2 & -22.7 & -21.7 & -19.6 & -20.0 & -21.3 & -22.6 & -24.0 \\
\hline Capital account & -1.9 & -1.2 & -0.4 & -4.6 & -0.4 & -0.5 & 0.0 & 0.0 & 0.0 & 0.0 & 0.0 & 0.0 \\
\hline Financial account & -1.3 & -5.4 & -0.6 & 1.6 & -11.8 & -22.2 & -21.7 & -19.6 & -20.0 & -21.3 & -22.6 & -24.0 \\
\hline Direct investment & -4.5 & 39.0 & -17.4 & 5.5 & 1.0 & -14.1 & -21.5 & -18.1 & -14.5 & -10.6 & -6.3 & -1.6 \\
\hline Abroad & -24.4 & -21.9 & -40.7 & -6.4 & -10.7 & -17.4 & -12.4 & -11.7 & -11.2 & -10.9 & -10.7 & -10.7 \\
\hline In Sweden & 19.8 & 60.9 & 23.3 & 11.9 & 11.7 & 3.3 & -9.1 & -6.4 & -3.3 & 0.3 & 4.4 & 9.1 \\
\hline Portfolio investment excl. fin. derivatives & -14.9 & -35.7 & -3.1 & -13.1 & -11.1 & -9.1 & -17.4 & -17.0 & -16.6 & -16.2 & -15.8 & -15.2 \\
\hline $\begin{array}{l}\text { Other investment } \\
\text { Official }\end{array}$ & 23.9 & -6.5 & 20.5 & 13.3 & -0.9 & 2.0 & -5.3 & -12.5 & -12.3 & -12.1 & -11.9 & -11.6 \\
\hline Reserve assets & -3.3 & -2.0 & -0.3 & 1.0 & -0.8 & -2.0 & 22.5 & 28.0 & 23.5 & 17.6 & 11.3 & 4.4 \\
\hline Net errors and omissions & -6.5 & -4.1 & -8.9 & -6.8 & -0.7 & 3.4 & 0.0 & 0.0 & 0.0 & 0.0 & 0.0 & 0.0 \\
\hline \multicolumn{13}{|l|}{ Memorandum items } \\
\hline GDP at current prices & 248.1 & 251.3 & 239.9 & 219.5 & 242.0 & 302.7 & 336.5 & 348.5 & 363.5 & 380.0 & 397.2 & 415.2 \\
\hline
\end{tabular}

Sources: Riksbank, and staff projections. 
Table 4. Sweden: Indicators of External and Financial Vulnerability, 1998-2004 (In percent of GDP, unless otherwise indicated)

\begin{tabular}{lllllllll}
\hline & 1998 & 1999 & 2000 & 2001 & 2002 & 2003 & 2004 & $1 /$ \\
\hline
\end{tabular}

\section{External Indicators}

Exports of goods and services (annual percentage change, in U.S. dollars) Imports of goods and services (annual percentage change, in U.S. dollars)

Current account balance

Capital and financial account balance

Direct investment, net

Portfolio investment, net

Central Bank reserves (end of period, in billions of U.S. dollars)

Exchange rate against US dollar (SEK, period average)

Exchange rate against Euro (SEK, period average)

Effective exchange rate (annual percentage change)

Real effective exchange rate (based on ULC, annual percentage change)

$3.0 \quad 1.4$

$6.1 \quad 1.6$

$3.9 \quad 4.3$

$-1.3-2.6$

$-1.8 \quad 15.5$

$-6.0-14.2$

$16.9 \quad 18.0$

$7.9 \quad 8.3$

$8.9 \quad 8.8$

$-2.1 \quad-1.4$

$-1.6-3.0$

\section{Financial Markets Indicators}

Consolidated public sector gross debt (end of period)

3-month T-bill yield (nominal, in percent per annum)

3-month T-bill yield (ex post real, in percent per annum)

Spread of 3-month T-bill vs. Germany (percentage points, end of period)

General stock index (annual percentage change)

Real estate price index (annual percentage change)

Commercial property price index (annual percentage change)

Credit to households (growth rate in percent, end of period)

\section{Financial Sector Risk Indicators}

Banks' return on equity after tax in four major banks

Nonperforming loans in four major banks (percent of lending)

Loan loss provisioning in four major banks (percent of lending)

Corporate borrowing ratio in percent

Ratio of households' financial liabilities to disposable income in percent

Ratio of households' interest payments to to disposable income in percent
Spread of 10-year T-bill vs. Germany (percentage points, end of period)

Tier 1 capital ratio in four major banks

$\begin{array}{rrrr}-9.4 & 8.1 & 22.8 & 18.0 \\ -10.5 & 5.7 & 22.3 & 17.6 \\ 4.4 & 5.4 & 6.4 & 6.4 \\ -1.4 & -5.1 & -7.5 & -6.4 \\ 2.5 & 0.4 & -4.7 & -6.4 \\ -6.0 & -4.6 & -3.0 & -5.2 \\ 14.8 & 19.3 & 22.4 & . . \\ 10.3 & 9.7 & 8.1 & 7.6 \\ 9.3 & 9.2 & 9.1 & 9.1 \\ -8.4 & 1.6 & 4.8 & 3.8 \\ -9.2 & 2.4 & 5.8 & 4.8\end{array}$

May

May

May

May

$\begin{array}{rrrrrrrr}69.4 & 62.7 & 52.8 & 54.4 & 52.6 & 51.9 & 52.1 & \\ 3.4 & 3.4 & 4.0 & 3.7 & 3.6 & 2.6 & 2.0 & \text { May } \\ 3.0 & 3.1 & 2.7 & 1.1 & 1.2 & 0.5 & 1.3 & \text { May } \\ 0.1 & 0.1 & -0.8 & 0.4 & 0.7 & 0.5 & -0.1 & \text { May } \\ 0.3 & 0.4 & -0.1 & 0.4 & 0.5 & 0.4 & 0.3 & \text { May } \\ 16.9 & 71.0 & -11.9 & -19.8 & -41.7 & 29.0 & 31.4 & \text { May } \\ 9.6 & 9.2 & 11.0 & 8.0 & 6.3 & 6.6 & 7.4 & \text { Q1 } \\ 10.1 & 7.5 & 6.9 & 0.9 & 11.4 & -5.2 & \ldots & \\ 6.6 & 9.0 & 7.5 & 8.9 & 9.3 & 10.1 & 10.4 & \text { April }\end{array}$

Sources: Statistics Sweden; Riksbank; Ministry of Finance; Datastream; INS; and staff calculations.

1/ Staff projections unless otherwise indicated.

\begin{tabular}{rrrrrrr}
6.9 & 7.9 & 6.9 & 7.0 & 7.1 & 7.4 & 7.4 \\
14.2 & 16.0 & 15.7 & 13.0 & 10.1 & 12.3 & $\ldots$ \\
2.6 & 1.8 & 1.6 & 1.5 & 1.2 & 1.2 & 1.2 \\
0.6 & 0.3 & 0.4 & 0.4 & 0.3 & 0.4 & 0.3 \\
73.4 & 75.8 & 79.8 & 83.3 & 76.5 & 70.2 & $\ldots$ \\
99.1 & 102.1 & 107.0 & 111.8 & 113.3 & 120.4 & $\ldots$ \\
4.9 & 4.6 & 4.8 & 4.8 & 4.8 & 4.4 & $\ldots$ \\
& & & & & & \\
\hline
\end{tabular}

March
March
March 
Table 5. Sweden: Public Sector Debt Sustainability Framework, 1999-2009

(In percent of GDP, unless otherwise indicated)

\begin{tabular}{|c|c|c|c|c|c|c|c|c|c|c|c|c|c|c|}
\hline & \multicolumn{5}{|c|}{ Actual } & & & \multicolumn{6}{|c|}{ Projections } & \multirow{3}{*}{$\begin{array}{c}\text { Debt-stabilizing } \\
\text { primary } \\
\text { balance 11/ }\end{array}$} \\
\hline & 1999 & 2000 & 2001 & 2002 & 2003 & & & 2004 & 2005 & 2006 & 2007 & 2008 & 2009 & \\
\hline & & & & & & & & \multicolumn{6}{|c|}{ I. Baseline Projections } & \\
\hline $\begin{array}{l}1 \text { Public sector debt } 1 / \\
\text { o/w foreign-currency denominated }\end{array}$ & $\begin{array}{l}62.6 \\
13.3\end{array}$ & $\begin{array}{r}52.9 \\
9.9\end{array}$ & $\begin{array}{l}54.4 \\
10.5\end{array}$ & $\begin{array}{r}52.6 \\
9.0\end{array}$ & $\begin{array}{l}51.9 \\
13.9\end{array}$ & & & $\begin{array}{l}\mathbf{5 2 . 1} \\
14.0\end{array}$ & $\begin{array}{r}51.5 \\
13.9\end{array}$ & $\begin{array}{l}\mathbf{5 0 . 6} \\
13.6\end{array}$ & $\begin{array}{l}49.5 \\
13.3\end{array}$ & $\begin{array}{l}\mathbf{4 8 . 4} \\
13.0\end{array}$ & $\begin{array}{l}\mathbf{4 7 . 5} \\
12.8\end{array}$ & 0.4 \\
\hline \multirow{2}{*}{$\begin{array}{l}2 \text { Change in public sector debt } \\
3 \text { Identified debt-creating flows }(4+7+12)\end{array}$} & -6.7 & -9.7 & 1.4 & -1.8 & -0.7 & & & 0.2 & -0.5 & -0.9 & -1.1 & -10 & -1.0 & \\
\hline & -3.8 & -8.5 & -5.0 & -4.9 & -4.8 & & & -2.6 & -3.3 & -3.8 & -3.3 & -3.3 & -3.2 & \\
\hline $\begin{array}{lr}4 & \text { Primary deficit } / 12 \\
5 & \text { Revenue and grants }\end{array}$ & -6.1 & -7.5 & -7.7 & -4.2 & -2.7 & & & -2.7 & -3.1 & -3.7 & -3.7 & -3.7 & -3.7 & \\
\hline \multirow{2}{*}{$\begin{array}{ll}5 & \text { Revenue and grants } \\
6 & \text { Primary (noninterest) expenditure }\end{array}$} & 59.1 & 58.3 & 59.0 & 56.6 & 56.1 & & & 55.9 & 55.5 & 55.4 & 55.1 & 54.8 & 54.6 & \\
\hline & 53.0 & 50.8 & 51.2 & 52.4 & 53.4 & & & 53.2 & 52.5 & 51.7 & 51.5 & 51.2 & 50.9 & \\
\hline \multirow{2}{*}{$\begin{array}{l}7 \\
8 \text { Automatic debt dynamics } 2 / \\
\end{array}$} & 2.3 & 2.3 & 2.9 & -0.7 & -1.6 & & & 0.7 & 0.3 & 0.5 & 0.4 & 0.4 & 0.4 & \\
\hline & 1.3 & 0.7 & 1.5 & 1.3 & 0.2 & & & 0.7 & 0.3 & 0.5 & 0.4 & 0.4 & 0.4 & \\
\hline $\begin{array}{l}8 \text { Contribution from interest rate/growth differential 3/ } \\
9 \quad \text { Of which contribution from real interest rate }\end{array}$ & 4.3 & 3.2 & 2.0 & 2.4 & 1.0 & & & 2.0 & 1.6 & 1.7 & 1.6 & 1.6 & 1.6 & \\
\hline $0 \quad$ Of which contribution from real GDP growth & -3.0 & -2.6 & -0.5 & -1.1 & -0.8 & & & -1.3 & -1.3 & -1.2 & -1.2 & -1.2 & -1.2 & \\
\hline Contribution from exchange rate depreciation $4 /$ & 1.0 & 1.7 & 1.3 & -2.0 & -1.8 & & & & & & & & & \\
\hline 2 Other identified debt-creating flows & 0.0 & -3.3 & -0.1 & 0.0 & -0.6 & & & -0.6 & -0.6 & -0.5 & 0.0 & 0.0 & 0.0 & \\
\hline \multirow{2}{*}{$\begin{array}{ll}3 & \text { Privatization receipts (negative) } \\
4 & \text { Recognition of implicit or contingent liabilities }\end{array}$} & 0.0 & -3.3 & -0.1 & 0.0 & -0.6 & & & -0.6 & -0.6 & -0.5 & 0.0 & 0.0 & 0.0 & \\
\hline & 0.0 & 0.0 & 0.0 & 0.0 & 0.0 & & & 0.0 & 0.0 & 0.0 & 0.0 & 0.0 & 0.0 & \\
\hline $5 \quad$ Other (specify, e.g. bank recapitalization) & 0.0 & 0.0 & 0.0 & 0.0 & 0.0 & & & 0.0 & 0.0 & 0.0 & 0.0 & 0.0 & 0.0 & \\
\hline 6 Residual, including asset changes (2-3) $5 /$ & -3.0 & -1.3 & 6.4 & 3.1 & 4.1 & & & 2.8 & 2.7 & 2.8 & 2.2 & 2.2 & 2.2 & \\
\hline Public sector debt-to-revenue ratio $1 /$ & 106.0 & 90.8 & 92.2 & 92.8 & 92.4 & & & 93.2 & 92.8 & 91.3 & 89.8 & 88.3 & 87.0 & \\
\hline Key Macroeconomic and Fiscal Assumptions & & & & & & $\begin{array}{c}\text { Historical } \\
\text { Average }\end{array}$ & $\begin{array}{r}\text { Standard } \\
\text { Deviation } \\
\end{array}$ & & & & & & & $\begin{array}{c}\text { Projected } \\
\text { Average }\end{array}$ \\
\hline Real GDP growth (in percent) & 4.6 & 4.3 & 0.9 & 2.1 & 1.6 & 2.9 & 1.4 & 2.5 & 2.6 & 2.5 & 2.5 & 2.5 & 2.5 & 2.5 \\
\hline \multirow{2}{*}{$\begin{array}{l}\text { Average nominal interest rate on public debt (in percent) } 7 / \\
\text { Average real interest rate (nominal rate minus change in GDP deflator, in percent) }\end{array}$} & 7.3 & 6.8 & 6.2 & 6.0 & 4.3 & 7.6 & 1.8 & 4.8 & 5.0 & 5.2 & 5.3 & 5.4 & 5.5 & 5.2 \\
\hline & 6.6 & 5.5 & 3.9 & 4.6 & 2.0 & 5.9 & 1.9 & 4.0 & 3.3 & 3.5 & 3.3 & 3.4 & 3.5 & 3.5 \\
\hline Nominal appreciation (increase in US dollar value of local currency, in percent) & -5.4 & -10.6 & -10.6 & 20.9 & 22.8 & 2.2 & 13.4 & & & & & $\ldots$ & & \\
\hline Inflation rate (GDP deflator, in percent) & 0.7 & 1.3 & 2.3 & 1.4 & 2.3 & 1.7 & 0.8 & 0.8 & 1.6 & 1.7 & 2.0 & 2.0 & 2.0 & 1.7 \\
\hline Growth of real primary spending (deflated by GDP deflator, in percent) & 5.0 & 0.0 & 1.9 & 4.5 & 3.6 & 1.0 & 2.6 & 2.0 & 1.3 & 1.0 & 2.0 & 2.0 & 2.0 & 1.7 \\
\hline Primary deficit & -6.1 & -7.5 & -7.7 & -4.2 & -2.7 & -3.9 & 3.9 & -2.7 & -3.1 & -3.7 & -3.7 & -3.7 & -3.7 & -3.4 \\
\hline A. Alternative Scenarios & & & & & & & & & . Stress & Tests for & Public D & t Ratio & & $\begin{array}{c}\text { Debt-stabilizing } \\
\text { primary } \\
\text { balance 10/ }\end{array}$ \\
\hline A1. Key variables are at their historical averages in 2005-09 8/ & & & & & & & & 52.1 & 51.7 & 51.5 & 51.1 & 50.8 & 50.5 & 1.4 \\
\hline A2. No policy change (constant primary balance) in 2005-09 & & & & & & & & 52.1 & 52.2 & 52.3 & 52.2 & 52.1 & 52.1 & 0.5 \\
\hline A3. Country-specific shock in 2005 , with reduction in GDP growth (relative to base & one stand & ard devia & ion 9/ & & & & & 52.1 & 51.5 & 50.6 & 49.5 & 48.4 & 47.5 & 0.4 \\
\hline B. Bound Tests & & & & & & & & & & & & & & \\
\hline B1. Real interest rate is at historical average plus two standard deviations in 2005 a & & & & & & & & 52.1 & 54.6 & 57.0 & 55.9 & 54.9 & 54.0 & 0.5 \\
\hline B2. Real GDP growth is at historical average minus two standard deviations in 200 & & & & & & & & 52.1 & 54.1 & 57.2 & 58.7 & 60.4 & 62.1 & 0.5 \\
\hline B3. Primary balance is at historical average minus two standard deviations in 2005 & & & & & & & & 52.1 & 58.4 & 65.0 & 64.0 & 63.1 & 62.2 & 0.5 \\
\hline B4. Combination of $2-4$ using one standard deviation shocks & & & & & & & & 52.1 & 57.3 & 63.0 & 62.0 & 61.1 & 60.3 & 0.5 \\
\hline B5. One time 30 percent real depreciation in $200510 /$ & & & & & & & & 52.1 & 58.1 & 57.2 & 56.2 & 55.2 & 54.3 & 0.5 \\
\hline B6. 10 percent of GDP increase in other debt-creating flows in 2005 & & & & & & & & 52.1 & 61.5 & 60.7 & 59.6 & 58.7 & 57.8 & 0.5 \\
\hline
\end{tabular}

1/ General government; gross deb

2/ Derived as $[(\mathrm{r}-\pi(1+\mathrm{g})-\mathrm{g}+\alpha \varepsilon(1+\mathrm{r})] /(1+\mathrm{g}+\pi+\mathrm{g} \pi))$ times previous period debt ratio, with $\mathrm{r}=$ interest rate; $\pi=$ growth rate of GDP deflator; $\mathrm{g}=$ real GDP growth rate; $\alpha=$ share of foreign-currency

denominated debt; and $\varepsilon=$ nominal exchange rate depreciation (measured by increase in local currency value of U.S. dollar)

$5 /$ For projections, this line includes exchange rate changes.

6/ Defined as public sector deficit, plus amortization of medium and long-term public sector debt, plus short-term debt at end of previous period.

7/ Derived as nominal interest expenditure divided by previous period debt stock.

8/ The key variables include real GDP growth; real interest rate, and primary balance in percent of GDP.

/ The implied change in other key variables under this scenario is discussed in the text.

(based on GDP deflator).

$12 /$ does not adjust for interest income receipts

(CInternational Monetary Fund. Not for Redistribution 
Table 6. Sweden: External Debt Sustainability Framework, 1999-2009

(In percent of GDP, unless otherwise indicated)

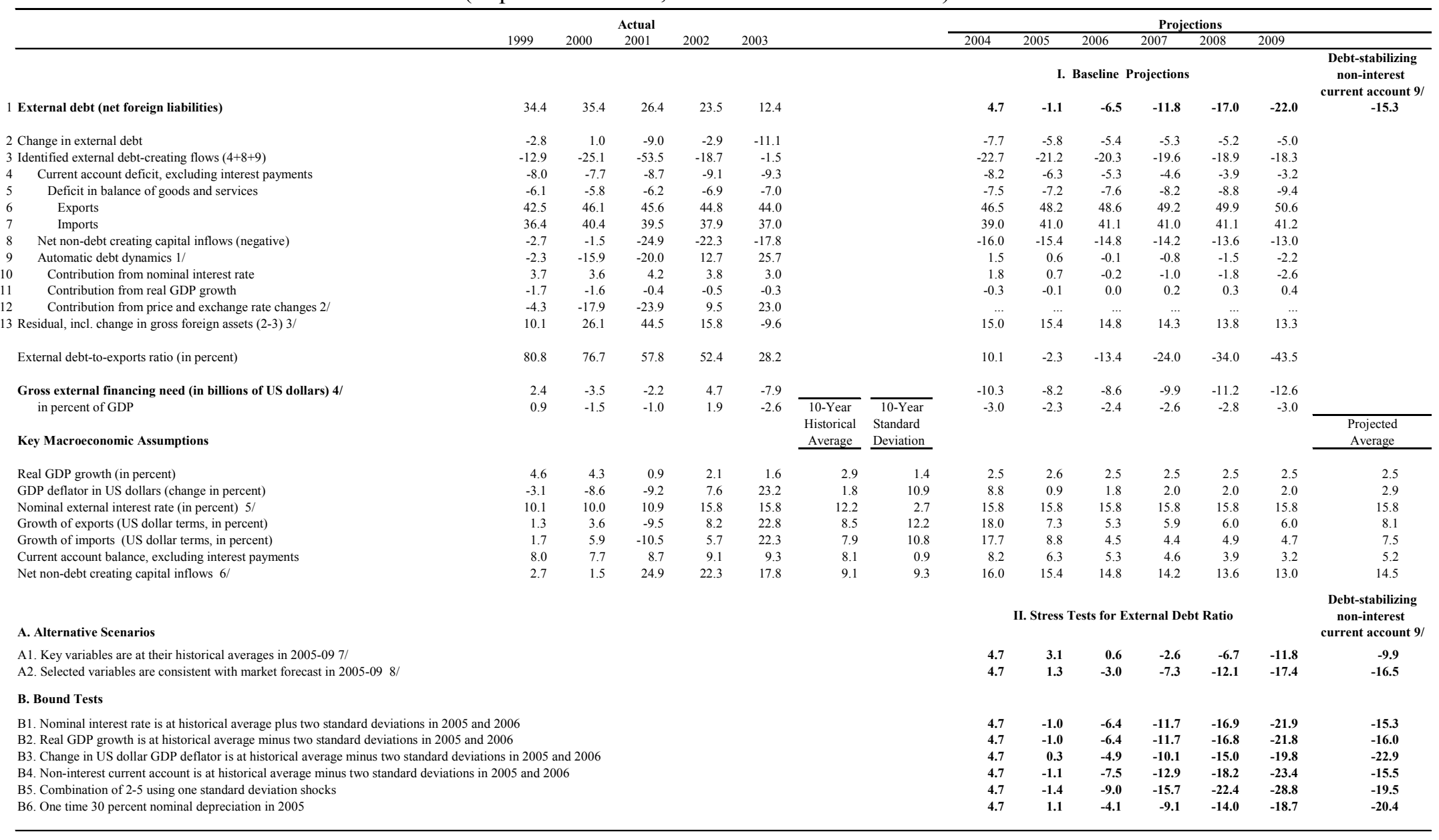

1/ Derived as $[\mathrm{r}-\mathrm{g}-\rho(1+\mathrm{g})+\varepsilon \alpha(1+\mathrm{r})](1+\mathrm{g}+\rho+\mathrm{g} \rho)$ times previous period debt stock, with $\mathrm{r}=$ nominal effective interest rate on external debt; $\rho=$ change in domestic GDP deflator in US dollar terms, $\mathrm{g}=$ real GDP growth rate, $\mathrm{e}=$ nominal appreciation (increase in dollar value of domestic currency), and $\mathrm{a}=$ share of domestic-currency denominated debt in total external debt.

$2 /$ The contribution from price and exchange rate changes is defined as $[-\rho(1+g)+\varepsilon \alpha(1+\mathrm{r})](1+\mathrm{g}+\rho+\mathrm{g} \rho)$ times previous period debt stock. $\rho$ increases with an appreciating domestic currency $(\varepsilon>0)$ and rising inflation (based on GDP deflator). 3/ For projection, line includes the impact of price and exchange rate changes.

4/ Defined as current account deficit, plus amortization on medium- and long-term debt, plus short-term debt at end of previous period.

5/ Historical average and standard deviation are calculated on the period 1996-2003.

6/ Historical average and standard deviation are calculated on the period 1995-2003.

7/ The key variables include real GDP growth; nominal interest rate; dollar deflator growth; and both non-interest current account and non-debt inflows in percent of GD

8/ Based on Consensus Forecasts for real GDP, current account, and exchange rate.

9/ Long-run, constant balance that stabilizes the debt ratio assuming that key variables (real GDP growth, nominal interest rate, dollar deflator growth, and both non-interest current account and non-debt inflows in percent of GDP) remain at their levels of the last projection year 


\section{SWEDEN: FUND RELATIONS}

(As of April 30, 2004)

I. Membership Status: Joined 08/31/51;

$\underline{\text { Article VIII }}$

II. General Resources Account:

SDR Million

$2,395.50$

$1,483.76$

911.75

Reserve position in Fund

Financial Transaction Plan transfers (net)

III. SDR Department:

Net cumulative allocation

Holdings
31.00

SDR Million

246.53

113.80
Percent of Quota

100.00

61.94

38.06

Percent of Allocation

100.00

46.16

IV. Outstanding Purchases and Loans: None

V. Financial Arrangements: None

VI. Projected Obligations to Fund:

\begin{tabular}{llllll} 
(SDR Million; based on existing use of resources and present holdings of SDRs): \\
\cline { 2 - 6 } & $\underline{5004}$ & $\underline{2005}$ & $\underline{2006}$ & $\underline{2007}$ & $\underline{2008}$ \\
$\begin{array}{l}\text { Principal } \\
\text { Charges/Interest } \\
\text { Total }\end{array}$ & $\underline{1.14}$ & $\underline{2.30}$ & $\underline{2.30}$ & $\underline{2.30}$ & $\underline{2.31}$ \\
& $\underline{1.14}$ & $\underline{2.30}$ & $\underline{2.30}$ & $\underline{2.30}$ & $\underline{2.31}$
\end{tabular}

VII. Exchange Arrangements: The Krona has been floating since November 19, 1992. In accordance with IMF Executive Board Decision No. 144-(52-51), the Swedish authorities have taken a series of measures to freeze the accounts of listed terrorist groups. In accordance with EU regulations and the relevant UN Security Council resolutions, certain restrictions are maintained on the making of payments and transfers for current international transactions with respect to Iraq, Myanmar, certain individuals associated with the previous government of the former Republic of Yugoslavia, and Zimbabwe. In accordance with EU Regulation 147/2003, financing of and financial assistance related to military activities in Somalia are prohibited. Restrictions also apply with respect to the Taliban and individuals and organizations associated with terrorism. 
VIII. Article IV Consultation: Discussions for the 2003 Article IV consultation were held in Stockholm, May 6-15, 2003 and the staff report (IMF Country Report 03/230) was issued on August 5, 2003. The consultation was completed by the Executive Board on July 25, 2003.

IX. Technical Assistance: None

X. Resident Representative: None 


\section{SWEDEN: CORE STATISTICAL INDICATORS}

(As of June 15, 2004)

\begin{tabular}{|c|c|c|c|c|c|c|c|c|c|c|c|c|}
\hline & $\begin{array}{c}\text { Exchange } \\
\text { Rates }\end{array}$ & $\begin{array}{l}\text { Interna- } \\
\text { tional } \\
\text { Reserves }\end{array}$ & $\begin{array}{c}\text { Central } \\
\text { Bank } \\
\text { Balance } \\
\text { Sheet }\end{array}$ & $\begin{array}{c}\text { Reserve/ } \\
\text { Base } \\
\text { money }\end{array}$ & $\begin{array}{l}\text { Broad } \\
\text { Money }\end{array}$ & $\begin{array}{l}\text { Interest } \\
\text { Rates }\end{array}$ & $\begin{array}{c}\text { Consumer } \\
\text { Price } \\
\text { Index }\end{array}$ & $\begin{array}{l}\text { Exports/ } \\
\text { Imports }\end{array}$ & $\begin{array}{l}\text { Current } \\
\text { Account } \\
\text { Balance }\end{array}$ & $\begin{array}{c}\text { General } \\
\text { Govern- } \\
\text { ment } \\
\text { Balance }\end{array}$ & $\begin{array}{l}\text { GDP/ } \\
\text { GNP }\end{array}$ & $\begin{array}{c}\text { External } \\
\text { Debt/ } \\
\text { Debt } \\
\text { Service }\end{array}$ \\
\hline $\begin{array}{l}\text { Date of Latest } \\
\text { Observation }\end{array}$ & $\begin{array}{l}\text { June } 15, \\
2004\end{array}$ & June 7, 2004 & June 7, 2004 & $\begin{array}{l}\text { June } 7 \\
2004\end{array}$ & $\begin{array}{l}\text { June } 7 \\
2004\end{array}$ & $\begin{array}{l}\text { June } 15 \\
2004\end{array}$ & May 2004 & $\begin{array}{l}\text { March } \\
2004\end{array}$ & Q1 2004 & 2003 & Q1 2004 & Q1 2004 \\
\hline Date Received & $\begin{array}{l}\text { June } 15 \\
2004\end{array}$ & $\begin{array}{l}\text { June } 14 \\
2004\end{array}$ & $\begin{array}{l}\text { June } 14 \\
2004\end{array}$ & $\begin{array}{l}\text { June } 14 \\
2004\end{array}$ & $\begin{array}{l}\text { June } 14 \\
2004\end{array}$ & $\begin{array}{l}\text { June } 15 \\
2004\end{array}$ & $\begin{array}{l}\text { June } 11 \\
2004\end{array}$ & $\begin{array}{l}\text { June } 7 \\
2004\end{array}$ & $\begin{array}{l}\text { May } 24, \\
2004\end{array}$ & $\begin{array}{l}\text { April 15, } \\
2004\end{array}$ & $\begin{array}{l}\text { June } 9 \\
2004\end{array}$ & $\begin{array}{l}\text { May 24, } \\
2004\end{array}$ \\
\hline $\begin{array}{l}\text { Frequency } \\
\text { of Data }\end{array}$ & Daily & Weekly & Weekly & Weekly & Weekly & Daily & Monthly & Monthly & Quarterly & Annually & Quarterly & Quarterly \\
\hline $\begin{array}{l}\text { Frequency of } \\
\text { Reporting }\end{array}$ & Daily & Weekly & Weekly & Weekly & Weekly & Daily & Monthly & Monthly & Quarterly & Annually & Quarterly & Quarterly \\
\hline $\begin{array}{l}\text { Source of } \\
\text { Update }\end{array}$ & Commercial & Riksbank & Riksbank & Riksbank & Riksbank & Commercial & $\begin{array}{l}\text { Statistics } \\
\text { Sweden }\end{array}$ & $\begin{array}{l}\text { Statistics } \\
\text { Sweden }\end{array}$ & Riksbank & $\begin{array}{c}\text { Ministry of } \\
\text { Finance }\end{array}$ & $\begin{array}{l}\text { Statistics } \\
\text { Sweden }\end{array}$ & Riksbank \\
\hline $\begin{array}{l}\text { Mode of } \\
\text { Reporting }\end{array}$ & On Line & On line & On line & On-Line & On-Line & On-Line & On-Line & On-Line & On-Line & Publication & On-Line & On-Line \\
\hline Confidentiality & Public & Public & Public & Public & Public & Public & Public & Public & Public & Public & Public & Public \\
\hline $\begin{array}{l}\text { Frequency of } \\
\text { Publication }\end{array}$ & Daily & Weekly & Weekly & Weekly & Weekly & Daily & Monthly & Monthly & Quarterly & Annually & Quarterly & Quarterly \\
\hline
\end{tabular}

CInternational Monetary Fund. Not for Redistribution 


\section{Statement by the IMF Staff Representative \\ August 4, 2004}

The following information on economic and financial developments, which has become available since the release of the staff report, does not change the thrust of the staff appraisal.

1. Economic activity continues to pick up speed, led by the strength of exports. Although rising industrial orders augur well for industrial production and exports, the recovery has yet to spur growth in employment. Indeed, the unemployment rate-a lagging indicator — rose from 5.3 percent in May 2004 to 5.8 percent in June.

2. Inflation slowed further in June. The consumer price index rose by 0.5 percent in the year to June, as compared with a 12-month rate of 0.7 percent in May. The measure of underlying inflation was 1 percent, somewhat below market expectations. The Riksbank left its policy rate unchanged at 2 percent on June 23.

3. The krona depreciated slightly against the euro in July. It reached a threemonth low of Skr 9.2 per euro at end-July, but remained strong against the U.S. dollar. In terms of its trade-weighted index, the krona depreciated by 1 percent during June-July. 


\section{INTERNATIONAL MONETARY FUND}

\section{Public Information Notice}

EXTERNAL

RELATIONS

DEPARTMENT
Public Information Notice (PIN) No. 04/86

FOR IMMEDIATE RELEASE

August 9, 2004
International Monetary Fund

$70019^{\text {th }}$ Street, NW

Washington, D. C. 20431 USA

\section{IMF Concludes 2004 Article IV Consultation with Sweden}

On August 4, 2004, the Executive Board of the International Monetary Fund (IMF) concluded the Article IV consultation with Sweden. ${ }^{1}$

\section{Background}

The downturn experienced by the Swedish economy in 2002-03 was relatively mild, with growth remaining well above the EU average. Expansionary fiscal policy in 2002 underpinned private consumption. Private investment, however, remained weak and activity decelerated when the impact of public sector stimulus waned in the first half of 2003. With external demand picking up in the second half, activity resumed its strength. The steady upturn, driven by exports and household demand sustained by low interest rates, has continued in early 2004 .

Growth has been sustained by a strong rise in productivity, which, while partly cyclical, suggests significant efficiency gains from the diffusion of new technologies. Coupled with economic slack, productivity growth dampened inflation pressures, widening the room for monetary easing. Inflation fell rapidly back toward the 2 percent target and continued to decline in early 2004 on account of base-year effects, falling import prices and strong productivity growth. Inflation expectations have remained low, contributing to wage moderation.

The recovery, however, has yet to turn around the decline in employment and average hours worked. Unemployment rose sharply in the year to early 2004, reflecting continued labor

\footnotetext{
${ }^{1}$ Under Article IV of the IMF's Articles of Agreement, the IMF holds bilateral discussions with members, usually every year. A staff team visits the country, collects economic and financial information, and discusses with officials the country's economic developments and policies. On return to headquarters, the staff prepares a report, which forms the basis for discussion by the Executive Board. At the conclusion of the discussion, the Managing Director, as Chairman of the Board, summarizes the views of Executive Directors, and this summary is transmitted to the country's authorities.
} 
shedding by the business sector and financially constrained local governments. The average duration of unemployment increased as did youth unemployment. In recent years, the high rate of sickness absence has been primarily responsible for the fall in average hours worked.

Although sickness absence leveled off in 2003, the adverse impact of overall ill health on labor supply continued to rise as many on long-term sick leave shift to disability pension.

The competitive position remained strong, reflected in the large surplus on the external current account. The krona was broadly unchanged vis-à-vis the euro, but appreciated by over 6 percent in effective terms in the year to March 2004, reflecting the weaker U.S. dollar, and by 3 percent in real effective terms, measured by relative unit labor costs. Nevertheless, with the krona remaining undervalued and with no further worsening of the terms of trade, the current account surplus rose from 5.4 percent of GDP in 2002 to a record-high of 6.4 percent of GDP in 2003. Financial markets took in stride the rejection of the euro in the September 2003 referendum.

With inflation falling faster than expected and forecast to remain below target, the Riksbank eased policy aggressively in early 2004 . The policy rate was cut by 25 basis points in February 2004 and by another 50 basis points in early April to 2 percent, its lowest level for more than 50 years. The Swedish policy rate is now at the same level as in the euro area. Signaling the end of an easing cycle, the Riksbank left the rate unchanged in May and June.

The budget for 2004 is broadly neutral and only a marginal rise in the structural surplus of the general government is expected. The fiscal framework is built around a structural surplus target of 2 percent of GDP, complemented by expenditure ceilings for the central government and a balanced budget rule for the local authorities. However, with new spending initiatives in the Spring 2004 Budget, the surplus target is not expected to be met at least until 2007.

The margins under the expenditure ceilings are once again too narrow to provide any leeway in the event of unexpected shocks.

Economic activity is expected to pick up steadily in 2004-05 as the global recovery gathers pace. Adjusted for calendar effects, output is expected to rise by around 2 percent in 2004 , rather than the unadjusted forecast of $2 \frac{1}{2}$ percent. The supportive monetary and fiscal policy stance and rising household confidence should stimulate private consumption, and improved demand prospects and profit position of manufacturing should assist a revival in business investment. Barring a sustained spike in oil prices, strong productivity gains and moderate wage increases would be expected to keep inflation below the target of 2 percent. The external demand stimulus could be larger than expected, especially if the krona continued to remain undervalued. However, the recovery over the coming year is unlikely to be accompanied by substantial gains in employment, which could hold back consumer spending, and persistent excess capacity in manufacturing could again postpone the projected pick up in business investment. 


\section{Executive Board Assessment}

Executive Directors praised Sweden's strong economic performance in recent years, grounded in well-designed fiscal and monetary policy frameworks, and strong productivity gains that have succeeded in making the downturn in 2002-03 more moderate than the average in the European Union. Directors noted that such strong performance had been thus far consistent with the generous welfare state. They saw a need, however, to revitalize the agenda of structural reform in order to address the challenges of demographic transition and global economic integration.

Directors considered that economic activity should gather strength in the near-term, as the global recovery picks up pace and monetary and fiscal policies remain supportive. Directors noted, however, that in spite of the recovery, employment and average hours worked are still declining, with uncertain prospects for a reversal in this trend.

Directors concurred that, with inflation projected to be below target over the next two years, a policy of keeping interest rates on hold for the near term would be appropriate. They considered that, as the recovery gathers speed, monetary policy will need to be tightened, particularly if the fiscal stance is not adequately restrictive. Directors commended the Riksbank's success in achieving the inflation target that has earned it high credibility. Nevertheless, they saw some room for refining its communications strategy, by making explicit the role of judgment in inflation assessments and extending the forecast horizon beyond two years.

Directors noted that Sweden's fiscal framework has a good track record and its fiscal position remains favorable in a comparative EU context. Nevertheless, noting that efforts to attain the fiscal surplus target have slackened in the recent past, Directors emphasized that safeguarding the target is central to maintain confidence in Sweden's medium-term fiscal framework. Most Directors encouraged the authorities to consider a more ambitious fiscal adjustment in 2005-06 to demonstrate their continued commitment to the surplus target.

Directors observed that there are no margins left for error in the expenditure ceilings and that pressures on public spending are unlikely to ease significantly as spending on sickness and disability benefits may not decrease as much as expected. In Directors' view, strict adherence to expenditure ceilings remains a key instrument for restraining the growth of spending, maintaining credibility of the fiscal framework, and allowing for a reduction in the high tax burden to ease constraints on growth. Some Directors cautioned against continued use of ad hoc measures to meet fiscal targets, as they could undermine transparency and credibility of the fiscal framework.

Directors noted that the rising tensions in public finances are also evident at the level of local governments. Local authorities have raised income tax rates in order to meet the balanced budget requirement in a context of increasing demands for public services related to health care and elderly care. Noting that the rising tax burden also reflects insufficient policy coordination between central and local governments, Directors encouraged the authorities to consider 
improving fiscal coordination and the use of balancing grants from the central government. Directors also underlined the importance of efforts to review the complex capital tax system in view of the intensifying international competition over tax bases.

Directors underscored the need to reform the tax-benefit regime to improve work incentives and achieve the increase in labor supply needed to meet the authorities' ambitious employment and social policy objectives. In this context, Directors highlighted the importance of more effective steps to reduce sickness absence, better integration of immigrants into the labor force, and efforts to reverse the declining trend in youth participation. A number of Directors urged the authorities to make a concerted effort to mobilize public support to address the incentive aspects of sickness absence as a key requirement to make any significant progress in this area.

Directors viewed a strengthening of competition in product markets as a necessary component of the agenda for faster growth. Directors welcomed the authorities' efforts to promote greater competition between public and private sectors in the provision of public services.

They observed, however, that barriers to competition still remain significant in some sectors. Against this background, Directors recommended a faster pace of structural reforms, particularly in light of the challenges stemming from an ageing population, EU enlargement, and globalization.

Directors concurred that Sweden's financial system remains sound. They noted that bank profitability has improved and capital adequacy and loan loss provisions remain at satisfactory levels. Although household debt has continued to rise, low interest expenses and higher home values mitigate its burden. Considering overall credit risks well-contained, Directors encouraged continued careful monitoring of risks associated with potential fluctuations in property values or a rise in interest rates.

Directors praised the authorities' positive role in revitalizing the Doha Development Agenda and Sweden's high level of official development assistance, which, at 0.7 percent of GNP, remains one of the highest in the world.

Public Information Notices (PINs) form part of the IMF's efforts to promote transparency of the IMF's views and analysis of economic developments and policies. With the consent of the country (or countries) concerned, PINs are issued after Executive Board discussions of Article IV consultations with member countries, of its surveillance of developments at the regional level, of post-program monitoring, and of ex post assessments of member countries with longer-term program engagements. PINs are also issued after Executive Board discussions of general policy matters, unless otherwise decided by the Executive Board in a particular case. The Staff Report for the 2004 Article IV Consultation with Sweden is also available. 
Sweden: Selected Economic Indicators

\begin{tabular}{|c|c|c|c|c|c|c|c|c|}
\hline & 1998 & 1999 & 2000 & 2001 & 2002 & 2003 & $20041 /$ & $20051 /$ \\
\hline \multicolumn{9}{|l|}{ Real economy (in percent change) } \\
\hline Real GDP & 3.6 & 4.6 & 4.3 & 0.9 & 2.1 & 1.6 & 2.5 & 2.6 \\
\hline Domestic Demand & 4.4 & 3.5 & 3.9 & -0.2 & 0.9 & 1.0 & 1.6 & 3.0 \\
\hline $\mathrm{CPI} 2 /$ & 1.0 & 0.6 & 1.3 & 2.7 & 2.0 & 2.3 & 0.7 & 2.0 \\
\hline Open unemployment rate (in percent) & 6.5 & 5.6 & 4.7 & 4.0 & 4.0 & 4.9 & 5.5 & 5.2 \\
\hline $\begin{array}{l}\text { Participation in labor market programs (in } \\
\text { percent) }\end{array}$ & 4.1 & 3.3 & 2.6 & 2.5 & 2.6 & 2.1 & 2.3 & 2.0 \\
\hline Gross national saving (percent of GDP) & 21.1 & 21.8 & 22.6 & 22.2 & 22.1 & 22.1 & 21.6 & 21.4 \\
\hline Gross domestic investment (percent of GDP) & 17.2 & 17.5 & 18.5 & 17.7 & 16.8 & 15.8 & 15.2 & 15.8 \\
\hline \multicolumn{9}{|l|}{ Public finance (in percent of GDP) } \\
\hline General government balance & 1.9 & 2.3 & 5.1 & 2.9 & -0.3 & 0.5 & 0.3 & 0.6 \\
\hline Structural balance $3 /$ & -0.9 & 0.5 & 3.8 & 3.0 & -0.2 & 1.1 & 1.2 & 1.3 \\
\hline General government debt & 69.4 & 62.7 & 52.8 & 54.4 & 52.6 & 51.9 & 52.1 & 51.5 \\
\hline \multicolumn{9}{|l|}{ Money and credit (12-month, percent change) } \\
\hline $\mathrm{MO}$ & 5.1 & 11.9 & 2.0 & 8.8 & -0.9 & 2.7 & $\ldots$ & $\ldots$ \\
\hline M3 & 2.5 & 9.7 & 2.8 & 6.7 & 4.5 & 3.1 & $\ldots$ & $\ldots$ \\
\hline Credit to non-bank public & 6.9 & 5.6 & 9.1 & 8.8 & 4.2 & 2.7 & $\ldots$ & $\ldots$ \\
\hline \multicolumn{9}{|l|}{ Interest rates (year average) } \\
\hline Three-month interbank rate & 4.9 & 3.6 & 3.6 & 4.1 & 3.9 & 3.9 & $\ldots$ & $\ldots$ \\
\hline Ten-year government bond yield & 5.9 & 4.3 & 5.6 & 4.8 & 5.2 & 4.6 & $\ldots$ & $\ldots$ \\
\hline \multicolumn{9}{|l|}{ Balance of payments (in percent of GDP) } \\
\hline Trade balance & 6.2 & 6.2 & 5.7 & 6.2 & 6.9 & 7.0 & 7.5 & 7.2 \\
\hline Current account & 3.9 & 4.3 & 4.1 & 4.4 & 5.4 & 6.4 & 6.4 & 5.6 \\
\hline International reserves (in billions of US dollars) & 16.9 & 18.0 & 16.3 & 14.8 & 19.3 & 22.4 & $\ldots$ & $\ldots$ \\
\hline $\begin{array}{l}\text { Reserve cover (months of imports of goods and } \\
\text { services) }\end{array}$ & 2.3 & 2.4 & 2.0 & 2.1 & 2.6 & 2.4 & $\ldots$ & $\ldots$ \\
\hline \multicolumn{9}{|l|}{ Exchange rate (period average, unless otherwise stated) } \\
\hline Exchange rate regime & \multirow{2}{*}{\multicolumn{8}{|c|}{$\begin{array}{l}\text { Floating exchange rate } \\
\text { US } \$ 1=\text { Skr } 7.4515\end{array}$}} \\
\hline Present rate (May 31, 2004) & & & & & & & & \\
\hline Nominal effective rate $(1995=100)$ & 101.1 & 99.7 & 100.0 & 91.6 & 93.1 & 97.5 & $\ldots$ & $\ldots$ \\
\hline Real effective rate $(1995=100) 4 /$ & 103.8 & 100.6 & 100.0 & 90.8 & 93.0 & 98.3 & $\ldots$ & $\ldots$ \\
\hline
\end{tabular}




\section{Statement by Jon A. Solheim, Executive Director for Sweden and David Farelius, Senior Advisor to Executive Director August 4, 2004}

1. Our authorities wish to express their appreciation to the staff for the constructive discussions in Stockholm and for an interesting and useful report on the Article IV consultation. They also found the selected issues paper interesting and relevant. Let us also state that our authorities noted a change of tone between the main staff report and the concluding statement that was published at the end of the mission to Sweden. We welcome the more nuanced views of the staff report. Our authorities share many of the conclusions and views expressed in the report. On some important issues, in particular related to fiscal and structural policies, however, the views of our authorities are different from those expressed in the staff report.

2. After a three-year period of growth lower than potential, the activity of the Swedish economy is expected to pick up in 2004 and 2005, following the upswing in the international economy. Looking back it is clear that the Swedish economy managed to withstand the international recession better than most other European countries, despite the fact that it was hit severely by the problems in the telecommunications sector. The average rate of growth during the years 2001-2003 was 1.5 per cent for Sweden, compared to 1.1 per cent for EU-15 and 1 per cent for the euro area. Despite clear signs of an economic recovery the inflationary pressure is still low. In response to the low inflation pressure the Riksbank has decided to reduce interest rates by another 0.75 percentage points since the consultation in 2003 .

3. Our authorities agree with the staff that the fiscal and monetary policy frameworks have served Sweden well and that it is important to preserve the credibility of the policy framework. A sound and stable macroeconomic framework is important in order to promote a high and sustainable rate of economic growth and employment.

\section{Fiscal policy}

4. The central target for fiscal policy, adopted by the Government and Parliament, is to maintain a surplus in general government finances equivalent to 2 per cent of GDP on average over the business cycle. The main aim of this target is to strengthen the financial position of the general government sector in preparation for the consequences of the demographic changes that are expected over the coming decades. The surplus target is also important for maintaining sufficient scope for countercyclical variations of the fiscal balance without moving into a situation of excessive deficit.

5. The fiscal policy framework is further underpinned by the system of nominal expenditure ceilings for the central government budget and a balanced budget requirement for the local authorities. The Government agrees with the staff that the fiscal policy framework has worked well, although it is not until recently that it has come under more considerable strain due to weaker economic activity and increasing expenditure pressure at the local level. 
6. The Government remains firmly committed to the fiscal framework and the fiscal targets. In last year's Spring Fiscal Policy Bill the Government proposed a number of expenditure cuts in order to avoid a breach of the expenditure ceilings. If the fiscal development turns out to be weaker than expected, the Government is prepared to take further measures in order to make sure that the expenditure ceilings are respected.

7. According to the projections of this year's Spring Fiscal Policy Bill, fiscal developments will by and large be in line with the surplus target over the coming years. According to the current expenditure plans the structural surplus will gradually approach 2 per cent in 2006. In order not to jeopardize the projected upswing in the labor market the Government is reluctant to take further measures to increase the structural surplus until a decisive reduction in unemployment has been achieved.

8. It should be emphasized that the surplus target for fiscal policy is considerably more ambitious than those set by the EU within the Stability and Growth Pact. Also, the fiscal performance of Sweden is still among the best in the EU and the OECD.

9. The Government has taken note of the proposals in the staff report regarding possible measures to strengthen the fiscal policy framework and will consider them in the future process of refining the framework. However, the Government does not share the staff's view on the need to trim back the welfare state in order to lower tax rates. Tax cuts will be considered if they can be afforded, without jeopardizing the fiscal policy targets and the quality of public services.

\section{Monetary Policy}

10. Monetary policy has since the previous consultation been conducted against the background of sharply falling inflation in 2003 and in the beginning of 2004. The decline was largely related to an expected downward adjustment in energy prices following on from the large price rises in the beginning of 2003. Recurrent assessments that inflation one to two years ahead would be somewhat below the inflation target have warranted a more expansionary monetary policy. Consequently the Riksbank lowered the repo rate in two steps in February and April from 2.75 to 2.0 per cent.

11. Looking ahead, inflation is expected to be relatively stable in the coming year after which it is projected to increase gradually. Inflation is forecast to be in line with the Riksbank's target towards the end of the forecast period one to two years ahead. As also noted in the staff report, one special circumstance is that Statistics Sweden has decided to change the way it calculates the inflation rate as of January 2005. The rate of inflation as measured according to the new method is expected to average 0.2 percentage points lower per year than with the current method. The forecasts of inflation from January 2005 refer to the new definition. The change in the definition of CPI inflation is thus expected to imply a sudden drop in the registered inflation rate in January 2005. To avoid irregularity in monetary policy, however, it may be appropriate to allow a purely technical change of this kind to filter through gradually. 
12. The fact that the repo rate is low in historical terms indicates that it will need to be raised in the longer term. However, the future stance of monetary policy will as usual depend on new information on economic developments in Sweden and abroad and the effects these may have on inflation prospects in Sweden.

13. The Riksbank agrees with the staff report that the krona is undervalued, although the extent of this undervaluation is quite uncertain. The most recent inflation forecast was based on an assumption of an appreciation of some two per cent during the coming two years.

14. The staff report raises the issue of the role of communication on monetary policy. In 1999 the Riksbank published a statement clarifying the general circumstances under which deviations from the inflation target can be tolerated. The principles presented in that statement have been applied since then and appear to be well understood by the financial markets. The inflation target remains defined in terms of the CPI, but various definitions of underlying inflation are used to characterize the persistent component of CPI inflation. Nevertheless, it is always a difficult task to identify the sources of transitory movements in inflation and present such analyses in a pedagogically simple and transparent way. The Riksbank is continuously developing its methods to forecast the persistent movements in inflation and a longer forecast horizon will be examined if this is deemed to be appropriate.

15. In line with the findings in the Financial Stability Report published in June, the Riksbank agrees with the staff report that risks in the financial system appear well contained.

\section{Structural policies}

16. The Government agrees with the staff report that the key challenge of structural policies over the coming years is to raise and maintain a high level of employment. The financing of the Swedish welfare state is dependent on a high level of employment. An increase in employment would also help contain the upward pressure on local government tax rates.

17. A target implying that at least 80 per cent of those between 20 and 65 years of age shall be employed by the year 2004 has been adopted by the Government. According to current projections the target will not be reached in 2004, partly due to unfavorable demographic conditions.

18. The Government shares the staff concerns about sick leave developments. Several measures have been taken to curb the negative trend of the last years. In addition to the measures already implemented, the Government intends to present a new proposal for dealing with the high sickness costs. According to this new proposal the employer will be responsible for the first two weeks (instead of three) of sickness plus $15 \%$ of the cost for the remaining sickness period or until the person is granted a more permanent benefit. The purpose is to improve incentives for the employers to take active action to prevent and deal with work-related sickness. Taken together, the planned and implemented measures are expected to lead to a decline in the sick leave rate. There are already clear signs that the number of people on sick leave has started to decline. 
19. The Government will closely monitor developments in sick leave and employment figures, and will take action if needed to make sure that the corresponding targets are reached over the medium term. Cutting replacement rates will not, however, be a preferred means of achieving this as such a step would come into serious conflict with important social policy objectives. Instead, the Government will rely on administrative controls and a more uniform and strict application of existing rules.

20. The Government does not agree with the staff that the Swedish welfare state needs to be scaled down in order to improve conditions for economic growth. There is no simple, straight forward connection between the size of the welfare state and the economic growth of a country. Over the last ten years the Swedish economy has done better than that of many other OECD countries, despite the fact that the welfare state in Sweden is one of the largest in the OECD area, as a percentage of GDP. In fact, many of the expenditure items that are generally counted as part of the welfare state are likely to be positively connected with economic growth as they support a high labor supply and thus a better economic performance. This is in particular true for the subsidies to child care and the care for the elderly.

21. The Government agrees with the staff report on the need to strengthen competition in certain markets. The Government is aware of the problems in the housing market and the fact that the current system is not working properly in all respects. The challenge is to find a solution that does not compromise the fundamental principles of Swedish housing policy. The desire to maintain strong tenure rights rules out a completely market-based system. 